\title{
An analysis on the Impact of Foreign Direct Investment (FDI) on Economic Growth of Underdeveloped African Countries: A case study on Mali
}

\author{
Kone Dounambaphd Student \\ (Central China Normal University) \\ batosdelta@hotmail.com
}

\begin{abstract}
The aim of the research was to investigate the impacts of foreign direct investment (FDI) on economic growth of Mali and to find out ways to achieve desired inflow of FDI in Mali. The research has been conducted based on a methodology developed in the light of positivism research philosophy, deductive research approach, hybrid research method and survey questionnaire strategy. The data of the research has been collected from a group of 50 sample population including 5 economists, 10 university teachers, 5 officials from finance and commerce ministry and 5 officials from foreign affairs ministry of Mali, 15 local investors, 5 foreign investors and 5 officials of World Bank and IMF working in Mali. The sample population has been selected based on probability sampling method.

The major findings of the research are: current FDI inflow to Mali is insufficient to achieve desired economic growth. There is a strong relationship between FDI inflow and economic growth in Mali. Increased inflow of FDI can efficiently enhance economic growth of Mali whereas insufficient inflow of FDI can create strong block against the economic growth of Mali. The research result that increased inflow of FDI can enhance the technology transfer to Mali that will contribute to maximize economic productivity and GDP growth as well economic growth of the country. High inflow of FDI in Mali can maximize the skills and productivity of its workforce that will actively contribute towards economic development and growth of the country.

Mali can enjoy high level of FDI inflow based on the factors including sufficient low cost labor supply, transportation facilities, abundant low cost of raw materials supply, lower level of competition, high level of tax reduction opportunities, poor level of trade barriers, high flexibility of environmental legislation, and limited cultural distance with the western investors. But, the desired inflow of FDI can be blocked in case of high level of political instability and insecurity for foreign investor groups, insufficient supply of skilled labors, underdeveloped technology and infrastructures, insufficiently big host market and lack of seaports in Mali.

The major limitations of the research were limited academic time to complete the research as well as the small sample population to collect research data.
\end{abstract}

Key Words: FDI, Economic Growth, Underdeveloped African Countries, Mali

\section{CHAPTER-ONE: INTRODUCTION}

\subsection{Research background}

Wacker, (2011), has explained that in modern globalized world, foreign direct investment, precisely FDI is a highly important issue which can be defined as the controlling ownership in a business enterprise in one country by an entity in another country. International Monetary Firm (IMF) has defined FDI more clearly as the investment made to acquire lasting or long-term interest in enterprises operating outside of the economy of the investors (Anderson, 2010) ${ }^{1}$. FDI works as the double-bladed sword for the economic benefit of the country where FDI is invested and the country which invests (Boeh, 2004) ${ }^{2}$. When an underdeveloped country receives FDI, it receives inflow of foreign capital and funds whereas the capital and funds enhances the investment in

\footnotetext{
${ }^{1}$ Anderson, T., (2010): U.S. affiliates of foreign companies operations in 2008, Survey of Current Business, Vol. 90, No.11, 45-58

${ }^{2}$ Boehe, D.M., (2004). Interaction between TNC subsidiaries and the host country innovation system: The case of TNC subsidiaries in Brazil. Universidade Federal do Rio Grande do Sul, School of Management.
} 
addition to increase in transfer of skills, technology, and job opportunities in the receiving country (UNCTAD, 2010 and Franco and Carvalho, 2004). In contrast, these enhance the maximization of economic growth and stability within the economy of the country where FDI is injected.

From another end, the countries or companies want to make direct investment in an underdeveloped country aiming for cheap human and non human resources to conduct their business in a cost effective way which is not possible within home countries (Goedhuys, 2007). In this context, the underdeveloped countries have abundance of unused human and non-human resources which are suffering from inefficiency of utilization for the lack of sufficient investment. In this way the investor entities enjoys the facility to maximize their cost effectiveness, profitability and growth through making direct investment to an underdeveloped country (Adewumi, 2006). Additionally, the country enjoys the new market for their existing product to skim revenues from the unbeaten market and flexible business environment. So, for the investor countries or organization, FDI can gather higher profitability and growth in business (World Bank, 2008); the underdeveloped countries can be released from their poverty and poor economic development with the enhanced inflow FDI through ensuring maximum utilization of their resources as well as increased income level and further growth opportunity (IMF, 1999).

Consistent with the study of Keane et al., (2010) and Iliffe, (2007), Africa is one of the most potential regions all over the world as the region has huge deposits of natural resources and is a heaven of low costing labor supply. In addition to this, the region is a highly potentially unbeaten market whereas the developed countries are searching for new markets as their domestic markets are going to reach matured that is leading their growth in economy in a stable ground (USID, 2010). But, most of the countries within the region are underdeveloped as they are unable to use their resources for their economic growth and stability in case of dire lack of investment, capital or funds (Adewumi, 2006). In this situation, if the developed countries can provide efficient FDI flow within the African countries they will get access new markets, new resources and new growth and profitability which will maximize their existing home country development (Goldsmith, 2001). Most importantly, the African countries have huge unused human and non-human resource ${ }^{3}$. The research has focused on the ground from the ground of Mali.

Mali is one of the West African's country highly potential countries with abundance of natural resources ${ }^{4}$. It is the eighth largest African country and the third largest gold producers among African countries,Mali has 15 million peopleswith an area of $1.241 .238 \mathrm{sq} . \mathrm{km}$ from where it can manage abundance of cheap labor supply.

The economy of Mali is mainly dependent on agriculture and mining. The country has not been developed industrially although it has huge potentiality for the development of different industrial areas ${ }^{5}$, but also there is a huge potentiality for the development of agricultural product based industrial development.

Although the country has huge potentiality for astonishing economic development through industrial growth, from the period of independence in 1960 to now, it is one of the poorest countries of the world. Economists have strongly urged that the burning barrier for Mali to have desired economic growth is the drastic scarcity of investment that has retained the resources unused and created strong barrier to unleash huge potentiality of economic growth ${ }^{6}$. They have further claimed that only huge flow of FDI can provide the rusted wheel of Mali's economy to an incredible speed of growth ${ }^{7}$. But, there is no valid ground that can establish the view that huge inflow of FDI can bring desired economic growth in Mali and how can the inflow of FDI accelerate Mali's economy. In light of this gap, the research has been conducted and the research has validated the view that huge inflow of FDI can bring desired economic growth in Mali and identified in which area inflow of FDI can accelerate in Mali's economy.

\subsection{Problem statement}

\footnotetext{
${ }^{3}$ Utilised efficiently in African countries with FDI inflow to enhance the economic growth, employment and standard of lives (UNECA, 2012).
}

${ }^{4} \mathrm{Josz},(2013)$ and IMF, (2014)

${ }^{5}$ The country is one of the largest cotton producer countries with huge supply of low costing labor in Africa that lead the country for textile industrial revolution (McKee, 2013)

${ }^{6}$ In accordance with Kimenyi, (2014), Boisvert, (2015), Josz, (2013) and Oxfam, (2013).

${ }^{7}$ World Bank, 2010 and Van de Walle, 2012 
Mali is one of the highly potential underdeveloped West African countries ${ }^{8}$. The country has been independent since 1960, but although the country has huge potentiality, it has not been able to achieve desired economic growth (OECD, 2008). The country is one of the largest African countries in producing highest volume of cash crops, foods and grains huge cotton production ${ }^{9}$. But, the country is continuously facing substantial trade deficit is now still significantly relying on foreign aid to keep its economy alive.

Furthermore, the poor economic condition in Mali is causing different social and national problems like civil war, poorest standard of living, poor educational level, malnutrition and subhuman social structure (World Bank, 2010). Most of the national and international economists and economy research organization have agreed that Mali has huge potentiality to establish itself as economically developed country through achieving growth in economy with industrialization and accelerating domestic production ${ }^{10}$. They have further claimed that only the industrial development, significant increase in economic activities and domestic production can lead the country's economy to the desired level of growth and stability (UP, 2014). Unfortunately, such a poor country like Mali cannot afford desired and sufficient domestic supply of investment for the desired development and growth of these economic areas to maximize its economic growth (Boisvert, 2015). As a result, they have suggested that only substantial inflow of FDI can deliver the desired investment to maximize the growth of economic sectors as well growth of the economy (Wacker, 2011 and World Bank, 2013). But, the burning question, in which the research has mainly focused, was-

"How desired inflow ofFDI can maximize economic growth of Mali and how desired level of FDI inflow can be attained by Mali?"

1.3 Research aim and objectives

Aim:

The aim of the research was to investigate the impacts of FDI on economic growth of Mali and to find out ways to achieve desired inflow of FDI in Mali"

Objectives:

For the achievement of the aim detailed above, the research hasfocusedon the following objectives

1. To investigate the current status of FDI inflow in Mali

2. To analyze the impact of FDI on economic growth of Mali

3. To assess the barriers of FDI in Mali.

4. To find out possible ways to minimize the barriers to accelerateFDI inflow in Mali.

\subsection{Research questions}

The research has focused on two major classes of research question and these are the principle research questions and subsidiary research questions.

\section{Principle question:}

"What are the impacts of FDI on economic growth of Mali and how desired level of FDI inflow can be attained by Mali? "

\section{Sub-questions:}

1. What is the current status of FDI inflow in Mali?

2. What are the impacts of FDI on economic growth of Mali?

3. What are the major barriers of FDI in Mali?

4. How to minimize the barriers to enhance FDI inflow in Mali?

\subsection{Research rationale/significance}

Robert, (2006) and ITC, (2013), have revealed that the issue of the research can be detailed as Mali is suffering from extreme poverty. But, the country has the huge economic growth potentiality. The justification of the statement is that the country is with huge supply of human and non-human resources which are the preconditions for economic growth and development. In contrast, the desired development in Mali's economy has not been achieved over the past years in case of poor capital and investment supply. The reason behind it is that the country has very poor domestic investment supply. As a result, for the achievement of desired economic

\footnotetext{
${ }^{8}$ Robert, (2006) and ITC, (2013)

${ }^{9}$ International monetary fund 2014

${ }^{10}$ Kimenyi, (2014), Josz, (2013) and Oxfam, (2013), Wacker, 2011 and WITS, 2012).
} 
growth of Mali is only to have sufficient FDI $^{11}$. To justify the hypothetical statement, the research has been conducted to investigate how the desired FDI inflow can maximize the growth of Mali and how the FDI inflow can be achieved.

From country context, the research is highly important for highly potential for underdeveloped country as Mali. The research has investigated critically, how FDI inflow can maximize the economic growth by developing different economic sectors of the country. Furthermore, the research has investigated what are the major barriers before having desired FDI inflow to get desired economic development of Mali and how these can be removed. The research results will help the authority of Mali to understand the importance of FDI inflow to maximize its economic growth and what the major barrier to get it. Not only that but also, the research has revealed that how Mali can remove the barriers before to getting desired FDI inflow. So, the research will help the country to understand the importance of FDI and ways to get it that will maximize the investment injected within its economy and stimulate its economic growth.

From the regional perspective, the research will be highly important issue for all the countries in this region as more or less all the countries in this region have a similar economic and socio-economic condition. The research will inform the importance of FDI for achieving desired economic growth through having enhanced investment of capital within their economy. Additionally, they will get outlines of how they can grab the opportunity of economic growth based on enhanced FDI inflow within their economy. In this way; the research will significantly contribute to their economic growth and future development.

From a perspective, the research has helped to understand how to develop a research ground and how to develop theoretical and conceptual ground to conduct the research successfully. Most importantly, the research has helped to understand research methodology which is a basic requirement for being successful in professional life as business personnel. Furthermore, the research has helped to enhance data collection, data analysis and successful research operation skills. From this context, it can be said that the research was a milestone for the development of desired skill levels necessary to be a successful business personnel in highly competitive globalized business world.

\subsection{Research outlines}

The research has been conducted within a set five well-defined chapters. The first chapter has detailed the research background, research aim, objectives and questions, research rationale, brief research methodology and unique contribution of the research. In literature review of chapter two, the theoretical and conceptual grounds of the research have been designed. The analysis in literature review has generated research benchmarks which have helped to collect and analyze data to develop research results and findings. In chapter three, the methodology of the research has been detailed where different elements of research methodology including research philosophy, research approach; research strategy, sampling method as well as data analysis plan have been detailed and justified. In fourth chapter of the research, research data collected against the research aim and objectives have been presented and analyzed to generate research results. In chapter five, the research results have been compared with the benchmarks developed in chapter four to generate research findings. At the end of the research, entire work has been concluded and recommended in the light of conclusion according to the research aims and objectives based on the research findings.

\section{CHAPTER-TWO: LITERATURE REVIEW}

According to Dellinger \& Leech, (2007), literature review is the review of different previous studies regarding the current research topic. The major aim of a research literature review is to develop research benchmarks based on the analysis of different studies regarding the research ground (Green, Johnson and Adams, 2006). For the development of research benchmarks for the current research, a literature review has been developed. The literature review based benchmarks have helped to collect and analyze research data to generate research findings. The literature review has been developed in two major parts including theoretical framework and conceptual framework. The theoretical framework has developed theoretical framework or review and the conceptual framework has revealed different research results within the given research area. The research literature review two major types of variables and these are independent variables and dependent variable. The dependent variable for the research was the economic growth whereas independent variable was the FDI). The literature review has been developed within funnel approach where the elements of literatures have been arranged from broader to precise.

\footnotetext{
${ }^{11}$ Kimenyi, 2014
} 


\subsection{Theoretical framework: FDI and Economic Growth}

\subsubsection{Theoretical Framework: Foreign Direct Investment (FDI)}

Consistent with the study of Wacker, (2011), foreign direct investment, precisely FDI, is one of the major tools of international economy. It is used for the achievement of balanced development of global economy as it provides opportunities for the developing and underdeveloped countries all over the world to achieve economic growth to get desired development of the countries. FDI not only benefits the development of receiving countries but also it accelerates the economic growth of investors for maximizing their income and economic enrichment (Herzer et al., 2006). More clearly, Harrison and Rodríguey-Clare, (2009), have said that FDI strongly help the economic growth of the country with developing and underdeveloped economy as it offers huge investment and capital inflow within the economy and ensures economic growth. In contrast, the developed countries, organizations and investors with huge deposit of investable money can easily invest within the economies to have greater profit as the underdeveloped countries have huge supply of natural resources and cheap costing resources which maximizes the profitability of the countries, organizations and investors (Baltagi, et al., 2008).

In accordance with Demirhan and Masca, (2008), the term foreign direct investment (FDI) can be detailed generally as investing money or capital to a country beyond the national boarder. More deeply, the control of ownership in a business enterprise in one country by an entity based in another country is considered as FDI. In other way; according to Karim and Fleming, (2012), FDI can be defined as the ownership control of $10 \%$ or more of an enterprise's voting securities or the equivalent interest in an unincorporated business. Some economists like Albert \& Brian, (2009), have explained the term FDI in such a way that FDI is a package of capital, technology, management and entrepreneurship and the package permits a firm to operate and supply goods and services in a foreign market (Leitão \& Faustino, 2010). So, in a nut shell, FDI can be defined as the investments made by an organization, company and country in a company or country outside the national boarder of the home country . In other words, the investment made to acquire lasting or long-term interest in enterprises operating outside of the economy of the investors.

From the study of Sarkar, (2007),FDI can be in different forms; but most of the FDIs from one country to another country have some regular features. These are basic characteristics of FDI. As the first feature of FDI it can be said that FDI is less volatile than portfolio investment or bank loans. From a general point of view FDI among the developed countries is much greater than FDI from developed to developing or underdeveloped countries (Bair, 2005). From this context, it can be said that FDI will be small in figure when it will be offered to a small country (3) Total FDI data includes mergers \& acquisitions (M\&A), setting up branch offices, service FDI, energy and mineral extraction, and so on. Greenfield-type manufacturing FDI, most desired by developing countries, is only a small part of FDI flows. Another major feature of FDI is the long term nature that means FDI is the form of investment which is offered with a long term vision and purpose. There are three major types

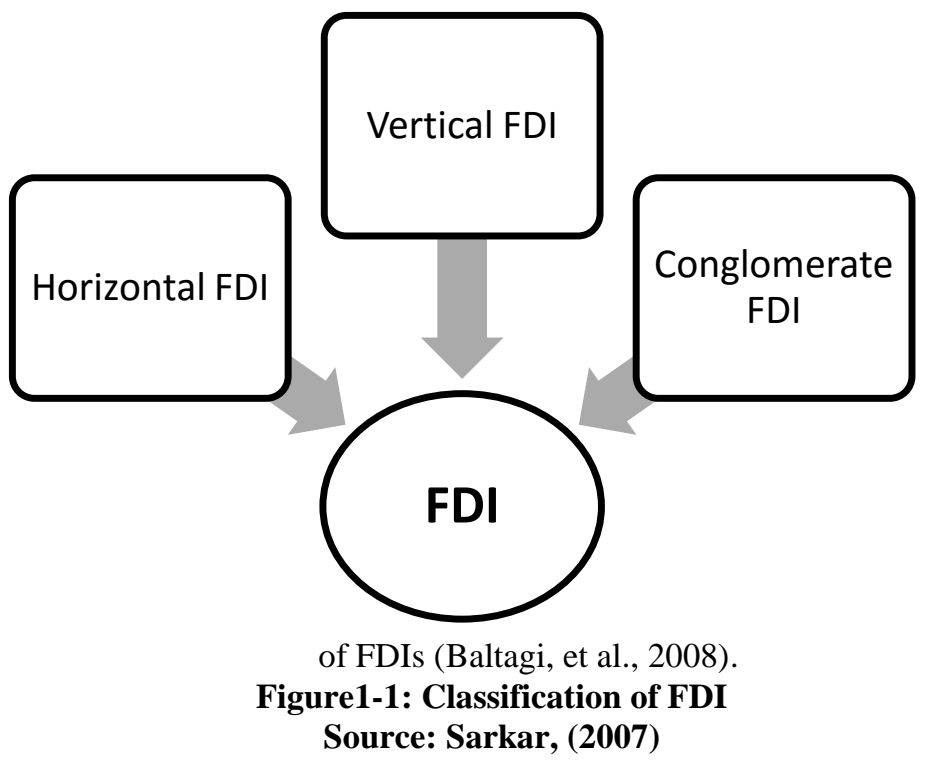

In the light of the study of Sarkar, (2007) and Ekholm, et a., (2007), horizontal FDI is a major form of FDI where the company or an institution carries out same activities abroad as at home. For example- The Japanese car manufacturer organization Toyota is assembling cars in both Japan and UK. But, these types of foreign direct investment in UK from Japan by Toyota are considered as the horizontal FDI form. The concept of 
vertical FDI can be detailed as when different stages are added abroad based on FDI (Harrison and RodrígueyClare, 2009). There are two major types of vertical FDIs and these are forward vertical FDI and backward vertical FDI. The forward vertical FDI takes the firms nearer to the market whereas the backward vertical FDI where international integration moves back towards raw materials (Herzer et al., 2006). The concept of conglomerate FDI is the concept where an unrelated business added to abroad and it is considered as the most unusual form of FDI as it involves attempting to overcome two barriers simultaneously including entering a foreign country and a new industry and it leads the analytical solution that internationalization and diversification are often alternative strategies, not complements (Asiedu, 2005).

According to Bhavan et al., (2011), Hailu, (2010) and Ho \& Rashid, (2011), the foreign direct investment in a country depends on different issues. The issues have been classified in different classes. The major classes of factors that strongly influence the FDI flow are:

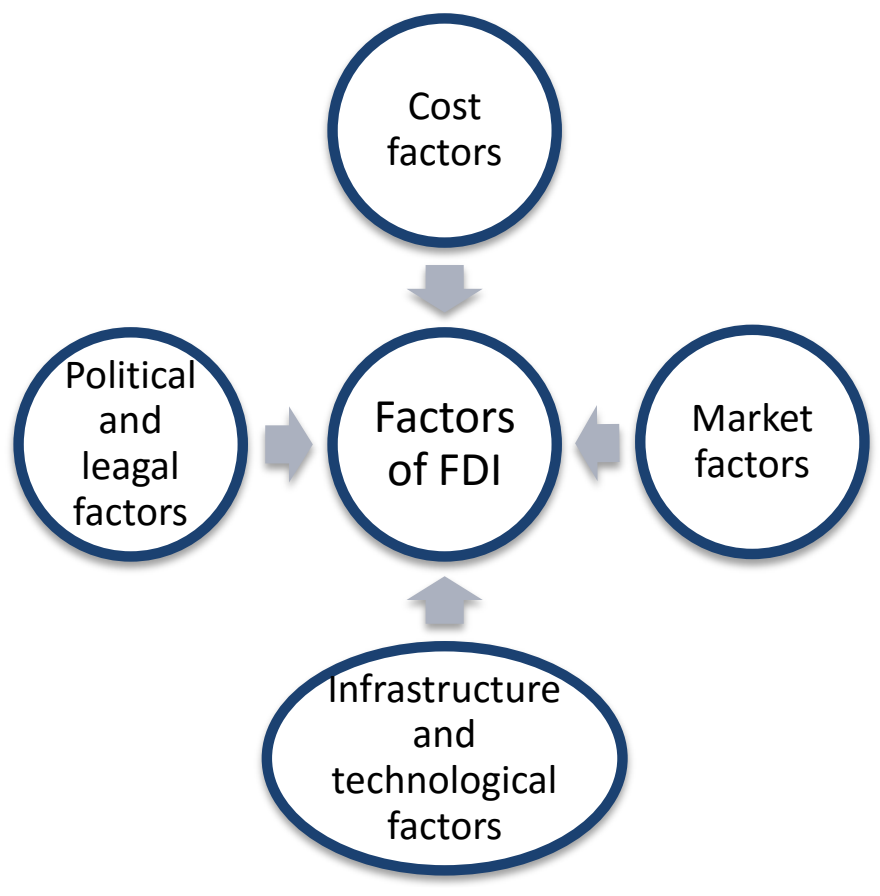

Figure-2: Factors of FDI

Source: Bhavan et al., (2011), and Hailu, (2010)

Consistent with the study of Demirhan and Masca, (2008) and Bhavan et al., (2011), the primary considering factor of FDI is the cost factors. When the FDI to a country will be proved as cost effective, the investors will be highly interested in the country to invest and the inflow of FDI to the country will be enhanced (Mohamed \& Sidiropoulos, 2010). In contrast, when the cost factors in a country are high, the country becomes unattractive to foreign investors that reduce the flow of foreign direct investment. The major cost factors are labor cost, transportation or logistic cost, low cost of raw materials and return on investment (Leitão, 2010).

Ang, (2008) and Leitão \& Faustino, (2010), have detained that the second most important group of factors that strongly influences the flow of FDI in a country is the market factors. Before investing in a foreign country, investors are highly concerned about the market potentiality of the country. If the country has huge potentiality in case of domestic market, the country becomes lucrative for foreign investors whereas when the country has poor scope in its domestic market, the country becomes unattractive for FDI (Mehic et al., 2009). The market potentiality for FDI within a country depends on some sub-factors including large size of host markets, demand in host country and level of competition (Mehic et al., 2009).

Almfraji and Almsafir, (2014), have revealed thatthe next FDI influencing factor considered by the foreign investors is infrastructure and technological factors. If a country is infrastructural and technologically developed, the inflow of FDI enhances as these are the precondition for financial and business benefits. In contrast, if a country is infrastructural and technologically underdeveloped, the inflow of FDI becomes low (Leitão \& Faustino, 2010). The major infrastructural and technological factors are level of infrastructural and technological development, industrial contraction, availability of well qualified workforce and access to reliable and cooperative suppliers (Azam, 2010). 
Schneider \& Matei, (2010), have explained that the last group of factors, which strongly influence the flow of FDI is the political and legal factors. If the country can manage a positive state of political and legal conditions, foreign investors become highly interested to invest in the country (Zenegnaw, 2010). In contrast, when a country cannot manage positive state of political and legal conditions, foreign investors become highly frustrated to invest in the country. The major political factors are; political stability, international trade agreements, tax reduction opportunities, trade barriers, strictness of environmental legislation, social and cultural state, cultural distance and attitudes of local community towards the firm (Demirhan and Masca, 2008).

\begin{tabular}{|c|c|}
\hline & \\
\hline $\begin{aligned} \text { Favorable cost factors: } \\
\square \quad \text { Cheap labor cost } \\
\square \quad \text { Low transportation or logistic cost } \\
\square \quad \text { Low cost of raw materials } \\
\square \quad \text { High return on investment } \\
\end{aligned}$ & $\begin{aligned} & \text { Unfavorable cost factors: } \\
& \square \text { High labor cost } \\
& \square \text { High transportation or logistic cost } \\
& \square \text { High cost of raw materials } \\
& \square \text { Low return on investment } \\
&\end{aligned}$ \\
\hline $\begin{aligned} \text { Favorable market factors: } \\
\quad \quad \text { Large size of host markets } \\
\square \quad \text { High demand in host country } \\
\square \quad \text { Low level of competition }\end{aligned}$ & $\begin{aligned} \text { Unfavorable market factors: } \\
\square \quad \text { Relatively small size of host markets } \\
\square \quad \text { Low demand in host country } \\
\square \quad \text { High level of competition }\end{aligned}$ \\
\hline $\begin{array}{l}\text { Favorable infrastructural and technological } \\
\text { factors: }\end{array}$ & $\begin{array}{l}\text { Unfavorable infrastructural and technological } \\
\text { factors: }\end{array}$ \\
\hline $\begin{array}{l}\text { High level of infrastructural and } \\
\text { technological development }\end{array}$ & $\begin{array}{l}\square \quad \text { Insufficientinfrastructural } \\
\text { technological development }\end{array}$ \\
\hline$\square \quad$ High industrial contraction & $\square \quad$ Poor industrial contraction \\
\hline $\begin{array}{l}\text { High availability of developed human } \\
\text { resources }\end{array}$ & $\begin{array}{l}\text { Low availability of developed human } \\
\text { resources }\end{array}$ \\
\hline $\begin{array}{l}\square \text { High access to reliable and } \\
\text { cooperative suppliers }\end{array}$ & $\begin{array}{l}\square \text { Poor access to reliable and } \\
\text { cooperative suppliers. }\end{array}$ \\
\hline Favorable political and legal factors: & Unfavorable political and legal factors: \\
\hline $\begin{array}{l}\square \quad \text { High level of political stability } \\
\square \quad \text { Favorable international trade }\end{array}$ & $\begin{array}{l}\square \quad \text { High level of political instability } \\
\square \quad \text { Unfavorable international trade }\end{array}$ \\
\hline$\square \quad$ High tax reduction opportunity & $\square \quad$ Poor tax reduction opportunity \\
\hline$\square \quad$ Low trade barrier & $\square \quad$ High trade barrier \\
\hline$\square \quad$ Flexible environmental legislation & $\square \quad$ Inflexible environmental legislation \\
\hline social and cultural state & $\square \quad$ Unfavorable social and cultural state \\
\hline$\square \quad$ Low & $\square \quad$ High cultural distance \\
\hline $\begin{array}{l}\square \quad \text { Positive attitudes of local community } \\
\text { towards the firm. }\end{array}$ & $\begin{array}{l}\text { Hostile attitudes of local community } \\
\text { towards the firm. }\end{array}$ \\
\hline
\end{tabular}

Source: Bhavan et al., (2011), Ang, (2008), Almfraji and Almsafir, (2014) and Schneider \& Matei, (2010)

According to Zenegnaw, (2010), most of the countries all over the world wants to enhance their FDI flow into their country as it significantly contributesto the development and growth of a country. For the developed and underdeveloped countries, FDI is vital for their growth and success economically. The reason behind it is that FDI works as the double-bladed sword for the economic benefit for the country where FDI is invested and the country which invests (Boeh, 2004). When an underdeveloped country receives FDI, it gets inflow of foreign capital and funds whereas the capital and funds enhances the investment in addition to increase in transfer of skills, technology, and job opportunities in the receiving country (UNCTAD, 2010 and Franco and Carvalho, 2004). In contrast, these enhance the maximization of economic growth and stability within the economy of the country where FDI is injected. From another end, the countries or companies want to make direct investment in an underdeveloped country aiming for cheap human and non human resources to conduct their business in a cost effective way which is not possible within home countries (Goedhuys, 2007). In this context, the underdeveloped countries have abundance of unused human and non human resources which are suffering from inefficiency of utilization for the lack of sufficient investment. In this way; the investor entities 
enjoys the facility to maximize their cost effectiveness, profitability and growth through making direct investment to an underdeveloped country (Adewumi, 2006).

Additionally, the country enjoys the new market for their existing product to skim revenues from the unbeaten market and flexible business environment. So, for the investor countries or organization to make FDI can result in higher profitability and growth in business (World Bank, 2008); the underdeveloped countries can be released from their poverty and economic development with the enhanced inflow FDI through ensuring maximum utilization of their resources as well income level and further growth opportunity (IMF, 1999). In addition to this, the higher inflow of FDI in a underdeveloped or developed country, it allows new variety of capital input in the country that cannot be achieved through financial investment or trade in goods and services (Umoh et al., 2012). The higher inflow of FDI strengthens the competition in the domestic market which maximizes the development of market and technology as well as differentiation. Not only that but also recipients of FDI often gain employee training in the course of operating the new business, which contributes to human capital development in the host country. It is evident that the profit gained by the FDI contribution to corporate tax revenues in the developed and underdeveloped recipient country (Shaikh, 2010).

Li \& Liu, (2005), have established thatfor all the countries all over the world, FDI is highly desired as it is an efficient tool for the growth and success of economy for all countries. But, the need of FDI is the basic need for underdeveloped and developing countries to achieve desired economic growth. Haile \& Assefa, (2006), have clarified the reason that that these types of countries have natural resources and workforce supply which cannot be used in case poor supply of domestic investment and capital. As a result, underdeveloped and developing countries are in dire need of foreign direct investment and they want to achieve more and more FDI. But, there are some barriers which make these countries face insufficient FDI inflow for achieving desired economic growth (Faras \& Ghali, 2009). If a country can successfully overcome these barriers, it can gain desired level of FDI inflow and achieve desired economic success of the country. The economic barriers of receiving FDI are high labor cost, high transportation or logistic cost, high cost of raw materials and low return on investment. Market related barriers that can reduce the FDI inflow within a country are; relatively small size of host markets, low demand in host country and high level of competition (Alfaro et al., 2004). Infrastructural and technological barriers are; insufficient infrastructural and technological development, poor industrial contraction, low availability of developed human resources and poor access to reliable and cooperative suppliers. Barriers before receiving FDI relating to political and legal environment of a country are high level of political instability, unfavorable international trade agreement, poor tax reduction opportunity, high trade barriers, inflexible environmental legislation, unfavorable social and cultural state, high cultural distance and hostile attitudes of local community towards the firm (Hailu, 2010).

\subsubsection{Theoretical Framework: Economic Growth}

Barro, (1996), has said that the term economic growth is one of the important issues in economics which can be defined as the increase in the capacity of an economy to produce goods and services in comparison from one period to another period. The measurement of economic growth can be made based on different nominal terms which include inflation or in real terms, which are adjusted for inflation. According to Helpman, (2004), for comparing one country's economic growth to another, GDP or GNP per capita should be used as these take into account population differences between countries. In another way; the economic growth is an increase in the production and consumption of goods and services of an economy or country and it entails increasing population or per capita consumption. The economic growth of a country is determined by the increase in GDP whereas literally economic growth refers to an economy that is getting bigger, not necessarily one that is getting better (Jones, 2002). More clearly, the term economic growth can be defied as the increase in market value of the goods and services produced by an economy over time and it is conventionally measured as the percentage of increase in real GDP (Argyrous, Forstater and Mongiovi, 2004).

Vladimir, (2011), has said that economic growth is desired by all the countries as it is directly linked with the overall development of economic conditions. When a country faces high economic growth, it improves the living standard of a country as growth is the important avenue through which per capita incomes can rise and absolute poverty can be reduced in developing nations (Garrett, 2009). This is why it is believed that economic growth cannot cure all the problems in an economy but the absence of the growth can kill an economy. The economic growth within a country significantly enhances the employment rate and reduces the unemployment rate of the country as growth creates new jobs, although the pattern of employment changes also (Klare, 2012). Not only that but also economic growth works as the accelerator effect of growth on capital investment of a country through rising demand and output, which encourage investment in capital that helps to sustain GDP growth by increasing hislong run aggregate supply (LRAS). When economic growth is achieved by an economy, it can generate high business confidence through making positive impacts on the profit and performance of firms (Galor, 2005). The growth in economy boosts tax revenues and generates the money to finance spending on public and merit goods and services without having to raise tax rates. Additionally, with 
efficient economic growth, a country can be richer, nation develops and innovation enhances (Hanushek and Ludger, 2008). From a different point of view, economic growth can depend on the distribution of higher incomes that could bypass the poorest in the society; economic growth can cause negative externalities including pollution, higher crime rates and congestion which actually reduce living standards; it can conflict with environment and unsustainable economic growth can cause boom and bust recession (Galor, 2005).

From the study of Easterly, (2007), it has been revealed that there are different factors and causes that lead the economic growth of a country. But the major two causes significantly control the growth of an economy and these are increase in wages, government spending, export and customer confidence, low income tax rising house prices, increase in capital and investment, working population and labor productivity, discovering new raw materials, technological development and political stability (Castells-Quintana and Royuela, 2012). In other way; the growth in an economy can be accelerated from discovery of natural resources, country's production, increase in physical investment and capitals. It is evident that when a growth in labor forces or human resources occurs and the human resources can be managed and utilized properly, the economy of the country experiences growth (Banerjee and Duflo, 2003). Another influential factor of economic growth is the improvement of technology. This could increase productivity with the same levels of labor, thus accelerating growth and development. The favorable institutional framework which regulates economic activity such as rules and laws enhance economic growth of a country significantly. So, if an economy wants to have desired growth and success, it must manage these factors properly. In contrast, if the country or economy fails to manage these factors efficiently, it can never be able to have its desired growth and success (Addison and Baliamoune-Lutz 2006).

\subsection{Conceptual Framework: Impact of FDI in Economic Growth of Underdeveloped Country}

From the analysis of research results of Almfraji and Almsafir, (2014), Sarkar, (2007) and Li \& Liu, (2005), it has been revealed that there is a strong and significant relationship between FDI and economic growth of developing and underdeveloped countries as the high inflow of FDI strongly accelerate the economic growth of these types of countries whereas the poor FDI inflow in the economy of these countries creates capital shortage that strongly reduces the economic growth (Solomon, 2011 and Haile \& Assefa, 2006).

According to the study of Karim and Fleming, (2012),for several decades FDI and economic growth have a relationship which it has been a topical issue in policy market. Policymakers in a large number of underdeveloped and developing countries are engaged in creating all kind of incentives ( export processing zones and tax incentives) to attract FDI, because it is proposed to affect local economic development positively Binsaeed, (2009). Researches of Azam, (2010), Bhavan et al., (2011) and Hailu, (2010), have established that FDI affects host economies through different channels, composition effects (changing market structures), competition effects, and employment effects and knowledge spillovers. Asiedu, (2005) and Herzer et al., (2006), have found that today, intra-firm trade (i.e. trade between subsidiaries and head quarters of multinational firms) may detect for one- third of total world trade and sales of multinational firms now exceeds worldwide exports of goods and services.

From another point of view, Wacker, (2011) and Baltagi, et al., (2008), have revealed that the growth of a country is determined by trend in GDP growth of the country. If the GDP of a country is higher, the growth of economy will be higher whereas if the GDP growth of a country is poor, the economic growth will be considered as poor. In the developing or underdeveloped countries, the capital or investment crisis is one of the major barriers to utilize their resources to achieve desired economic growth (Bhavan et al., 2011). From a contrast point of view, Azam, (2010) and Hailu, (2010), have revealed that when an underdeveloped or developing country gets high inflow of FDI, the economy can maximize utilization of their resources that maximize their domestic product. When domestic product becomes higher in volume leads the maximization of GDP as well economic growth. In contrast, when an underdeveloped or developing country doesnot desired FDI inflow, it cannot support desired capital supply for economic growth that leads poor economic growth (Zenegnaw, 2010 and Leitão, 2010).

From the study of Almfraji and Almsafir, (2014) and Demirhan and Masca, (2008), it has been revealed that one of the major reasons for the poor economic growth of developing and underdeveloped countries all over the world is the poor technology applied in production or other economic sectors. For the lack of developed technology, the countries cannot achieve desired growth and success in economic sectors (Bhavan al., 2011). But, the inflow of FDI can efficiently solve the problem of economic productivity within the country as the foreign direct investment enhances the technology transfer which enables the economy in underdeveloped or developing countries to enjoy highly developed technologies that maximize their production. The increased production enhances the economic growth of the countries (Leitão \& Faustino, 2010) in contrast, when an underdeveloped or developing country cannot achieve desired FDI inflow; it loses the opportunity to get developed technology as well increased productivity. In this way; the country cannot achieve desired economic growth (Hanushek and Ludger, 2008). 
According to the study results of Umoh et al., (2012) and Jadhav, (2012), productivity of human resources of a country is a significant factor that directly contributes on the economic growth of the country. In this way; the country with highly skilled labor force can maximize its production that will lead significant growth in an economy. In contrast, Jadhav, (2012), has explained thatthe country with unskilled labor force cannot maximize its production that will lead low level of economic growth in the industry. Most of the underdeveloped or developing countries suffer from lowly skilled labor base. But, Mohamed \& Sidiropoulos, (2010), have revealed that when FDI inflow increases, foreign investors make significant efforts and invest huge money on human resource development to maximize efficiency of labor force to facilitate their business operation and benefits. These efforts generates a highly skilled labor base for the country that makes direct influence on generating high productivity the economy and ensures higher growth in the economy of developed or underdeveloped countries (Faras \& Ghali, (2009).

In accordance with the studies by Durham, (2004) and Alfaro et al., (2004), it has been established that the increasing inflow of FDI within a country can maximize the integration of domestic economy with global economy that enhances balance between the export and import of the country that efficiently contributes towards economic growth of the country. Furthermore, Al-Iriani, (2007), has found that the inflow of FDI enhances competition in local market and firms' development and reorganization, which maximizes the production capacity of local firms and generates additional product from new organizations established by foreign investors. Some other research reports like Demirhan and Masca, (2008) and Zenegnaw, (2010), have revealed that when international organizations or investors directly invest in a country to make business, they make merger or joint ventures that enhance capacity of existing firms in the economy and maximize their contributions on the economic growth of the country. From the context of developing and underdeveloped these countries frequently suffer from high level of trade imbalance in case of insufficient international trade integration, less competition and underdeveloped business entities which reduces the economic productivity of the countries (Sarkar, 2007). When they get huge inflow of FDI, the economy of the country can reduce the barriers and can maximize their international trade balance, enhance constructive competition between local and international firms and maximize the capacity and productivity of domestic firms and international business entities (Li \& Liu, 2005). In this way; the overall economic growth and success of economy of the country is achieved. In contrast, the underdeveloped and developing countries that fail to have desired FDI inflow suffer from acute trade imbalance, underdeveloped and inefficient domestic business structures that leads poor economic growth (Castells-Quintana and Royuela, 2012).

In the studies of Faras \& Ghali, (2009) and Durham, (2004), it has been proven that FDI can stimulate the economic development of the country in which the investment is made, creating both benefits for local industry and a more conducive environment for the investor. It will usually create jobs and increase employment in the target country. It will enable resource transfer, and other exchanges of knowledge whereby different countries are given access to new skills and technologies (Alfaro et al., 2004). The equipment and facilities provided by the investor can increase the productivity of the workforce in the target country. But at the same time, it can bring significant demerits for the domestic economy of a country (Al-Iriani, 2007). Foreign direct investment can sometimes hinder domestic investment, as it focuses resources elsewhere. Occasionally as a result of foreign direct investment exchange rates will be affected, to the advantage of one country and the detriment of the other (Haile \& Assefa, 2006). Foreign direct investment may be capital-intensive from the investor's point of view, and therefore sometimes high-risk or economically non-viable. The rules governing foreign direct investment and exchange rates may negatively affect the investing country. Investment in certain areas is banned in foreign markets, meaning that an inviting opportunity may be impossible to pursue (Almfraji and Almsafir, 2014).

From a contrast point of view, Shaikh, (2010) and Umoh et al., (2012), Zenegnaw, (2010), have warned that FDI may not be a blessing for developing and underdeveloped countries. While FDIs may increase the aggregate demand of the host economy in the short run, via productivity improvements and technological transfers, critics have also raised concerns over the efficacy of purported benefits of direct investments (Schneider \& Matei, 2010). This theory follows the rationale that the long-run balance of payment position of the host economy is jeopardized when the investor manages to recover its initial outlay. Once the initial investment starts to turn profitable, it is inevitable that capital returns from the host country to where it originated from, that is the home country (Mohamed \& Sidiropoulos, 2010). FDI often did not lead to the improvement of the structure of production and accumulation in the host country, as foreign firms, guided by theory of product life cycle, is transferred abroad, mainly those of technology and the equipment that their country had lost the latest status (Sarkar, 2007).

According to Shaikh, (2010), Umoh et al., (2012), Solomon, (2011) and Faras, \& Ghali, (2009) although there are huge controversies on whether FDI can be good for the economy of a country, most of the economists have strongly agreed in a point that there is no alternative for underdeveloped and developing countries to receive FDI and enhance the flow of FDI in their country to achieve significant economic growth and development. Some of the researchers like Al-Iriani, (2007), Hailu, (2010) and Asiedu, (2005), have said that 
most of there are huge controversies for FDI, but how many countries can refuse it. Furthermore, they do many things for attracting FDI as it is the basic tool for the development of economy of a country. In the context of underdeveloped or developing countries, it is fundamental element for having desired economic growth (Almfraji and Almsafir, 2014). But, most of the time, the foreign investors consider some specific issues to invest in a country to make FDI. If a country can manage these issues properly, they get desired FDI and if they fail, they alsofail to achieve desired FDI and economic growth. If a country wants to achieve high inflow of FDI, it will maintain some factors (Ho \& Rashid, 2011). According to the studies of Bhavan et al., (2011), Ang, (2008), Almfraji and Almsafir, (2014) and Schneider \& Matei, (2010), The major factors are economic factors e.g. cheap labor cost, low transportation or logistic cost, low cost of raw materials, high return on investment; market factors including large size of host markets, high demand in host country and low level of competition; infrastructural factors including high level of infrastructural and technological development, high industrial contraction and high availability of developed human resources. Other most important factors to attract are high access to reliable and cooperative suppliers, high level of political stability, favorable international trade agreement, high tax reduction opportunity, low trade barrier, flexible environmental legislation, favorable social and cultural state, low cultural distance and positive attitudes of local community towards the firm (Almfraji and Almsafir, 2014 and Schneider \& Matei, 2010). If a country cannot manage the factors at minimum extent, the country cannot attract high inflow of FDI whereas the country that can manage the desired and required conditions of these factors can maximize the FDI inflow to its economy to facilitate its economic growth (Bhavan et al., 2011 and Ang, 2008).

\section{CHAPTER-THREE: RESEARCH METHODOLOGY}

Methodology is one of the highly important issue for the successful completion of a research, more the methodology will be valid, more research outcomes and research work will be also valid. Normally, the methods applied to a research are considered as the research method ${ }^{12}$. More broadly, the set of methods, approach, process, strategy and techniques applied in a research is considered as the research methodology for the research ${ }^{13}$. For the operation of current research a well-defined research methodology has been applied here. The reason for using the research methodology is that it has helped to gain the validity and reliability of the research as well as the research outcomes. The major parts of the research methodology applied to conduct current research are the philosophy, approach, method, strategy and techniques of the research.

\subsection{Research philosophy: Positivism \\ 3.1.1 Research philosophy theory}

Saunders et al., (2009), have explained that the well-established recognized guidance or knowledge base to formulate and conduct a research work is considered as the research philosophy. The research philosophy has been first developed by Plato and Aristotle. The reason to apply the research philosophy in a research is that it guides how validly the further elements of the research methodology will be set. There are three major research philosophies and these are the positivist research philosophy, interpretive research philosophy and the realism research philosophy ${ }^{14}$. The Positivism is the research philosophy, which guides to collect different previously studied research related reliable and valid research data and create hypothetical growth to conduct a research ${ }^{15}$. The major advantage to use the research philosophy to conduct a research is that it helps to collect valid and reliable research data, provides high level of control over the research operation and ensures maximum easy research operation. But the major weakness of the research philosophy is that it restricts the contribution of researcher within the research ${ }^{16}$. The research philosophy guides to conduct a research by interpreting the behavior and nature of human and objects. The major advantage of the philosophy is that it helps to collect highly in-depth research data and allows researchers contribution. In contrast, it can lead high bias propensity to

\footnotetext{
${ }^{12}$ Saunders et al.2009/Mertens \& McLaughlin, 2004

${ }^{13}$ Creswell, 20 Creswell, J. W., (2009). Research design: Qualitative, quantitative, and mixed methods approaches (3rd ed.). Thousand Oaks, CA: Sage.

${ }^{14}$ Cohen et al., 2007

${ }^{15}$ Saunders et al., (2007)
}

${ }^{16}$ Saunders et al., 2009 
conduct the research as it will suggest investigating very limited number of research respondents (Kasi, 2009). Realism is the research philosophy which suggests collecting research data and information only based on the experiment and practical experience oriented issues. This is why it is highly efficient to be applied in scientific research whereas it will not be suitable to apply in business research as there are different issues in a business research not possible to be experienced practically (Murname \& Willett, 2011).

\subsubsection{Research philosophy selection and justification}

In the current research operation positivism research philosophy has been applied where previously published reliable and valid data regarding current research has been collected first and then a hypothetical ground has been created based on the data to conduct the research (Saunders et al., 2007). The justification to apply the positivism research philosophy is that it has guided to collect only valid and reliable research data and generated desired level of control over the research operation that has ensured easy operation of the research (Saunders et al., 2009). But, in case of high propensity of biasness, the interpretivism research philosophy has been avoided whereas in case of unsuitability to apply in a business research, the realism research philosophy has not been applied here (Kasi, 2009 and Murname \& Willett, 2011)

\subsection{Research approach: Deductive \\ 3.2.1 Research approach theory}

Sekaran and Bougie, (2010), have explained that for the research operation it is necessary to set a research action plan whereas to set the action plan research approach is used. There are two major research approaches including the deductive approach and inductive research approaches. The research approaches are suitable in different individual situation according to the research context (Huffcut, 2010). As explained by Saunders et al., (2009), the deductive research approach is the guidance to formulate the research action plan where a restricted theoretical ground is developed first and then the research is conducted within this theoretical ground. In case of restricted nature it is called the top-to-bottom approach. The major advantage of this research approach is that it helps to generate maximum certainty to get a successful research and desired research outcomes. But the confined nature of the approach can maximize the propensity to get biased research results (Saunders et al., 2007). The inductive research approach is the guidance to formulate the research action plan where no theoretical ground is developed and the research is conducted within free manner after developing a research ground. In case of unrestricted nature it is called the bottom-up approach. The major advantage of the research approach is that the unconfined nature of the approach can minimize the propensity to get biased research results. But major disadvantage of the research approach is that it generates no guarantee to get a successful research and desired research outcomes ${ }^{17}$.

\subsubsection{Research approach selection and justification}

In the research operation, the deductive research approach has been selected and applied where a theoretical research ground has been developed first and the research has been conducted within this theoretical ground (Saunders et al., 2009). The reason behind the selection and application of the research approach in the research is that it has been agreed with the selection of research philosophy positivism as well as it has produced maximum guarantee to get desired research results and successful research (Saunders et al., 2007). In contrast, the inductive research approach has been avoided here as it would not support positivism research philosophy and lead the research to maximum uncertain situation.

\subsection{Research method: Hybrid or mixed structured \\ 3.3.1 Research method theory}

For conducting a valid research, it is necessary to generate valid research data according to the research nature and purpose ${ }^{18}$. There are three major recognized research methods including qualitative, quantitative and mixed structured research methods based on which the necessary research data can be collected. In the research, the mixed structured research method has been used. Consistent with the study of Creswell, (2009), the

\section{${ }^{17}$ Crowther \& Lancaster, 2008}

${ }^{18}$ Creswell, J. W., (2012). Qualitative inquiry and research design: Choosing among five traditions (3rd ed.). Thousand Oaks, CA: Sage. 
qualitative research method is the research method which helps to collect in-depth research data based on unrestricted data collection environment. The major advantage of the data collection method is that it generates only in-depth research data which is highly bias-free and contributes to generate unbiased research results. In contrast major disadvantage of the research method is that this research method generates such data which is highly tough to measure. This is why; it is not considered as perfect research method in all research situations. Consistent with the study of Saunders, (2009), the qualitative research method is the research method which helps collect highly quantifiable research data based on a restricted data collection environment. The major advantage of the research method is that the research method helps to generate only quantifiable and controlled research data whereas major disadvantage is that it discourages to collect in-depth research data which is required in different research situations. Thus it is not considered as the perfect research method in all research situations (Patton, 2002 and Creswell, (2012), have detailed that to solve the problems of qualitative and quantitative research methods' problems, these are not suitable in all situations of a research; researchers have generated another research method by combining both the qualitative and qualitative research methods. This is called as the hybrid, pragmatic or mixed structured research method. The major advantage of the research method is that the research method provides huge flexibility to conduct a research by allowing both qualitative and quantitative data collection where which is suitable.

\subsubsection{Research method selection and justification}

In the current research ,the mixed structured or hybrid research method has been used as it has helped to generate perfect research results where both qualitative and quantitative research methods are solely inefficient ${ }^{19}$ . The reason behind it is that in the situation where highly quantifiable research data is required, qualitative research method was inappropriate. In contrast, where the in-depth research data is required quantitative research method cannot support it. But the mixed structured method will efficiently helps in both the situations by allowing collection of both types of research data according to the research situation. Furthermore, it has helped to collect research data avoiding weaknesses of both qualitative and quantitative research methods successfully (Creswell, 2009).

\subsection{Research strategy: Survey questionnaire}

Gray \& Guppy, (2007), have detailed that there are different research strategies that can be applied to collect research data in different research context and nature. The most widely used forms of research strategies are the survey questionnaire strategy, observation strategy, in-depth interview strategy, focus group discussion strategy and ethnic analysis strategy (Kasi, 2009). In the current research, the survey questionnaire strategy has been applied. To apply the survey questionnaire strategy, a mixed structured survey questionnaire has been applied where there were both open-ended and close-ended research questions. The close questions have been applied where numeric research data was required whereas the open-ended questions have been applied where in-depth research data was required (McNiff \& Whitehead, 2002). In the light of Gray \& Guppy, (2007), the justification to select and apply the research approach is that it has helped support previous research methodology elements selections. For example, selection of positivism research philosophy, deductive research approach and mixed research method (Patton, 2002). The survey to collect research data has been done through three major research techniques including face-to- face survey, telephonic survey and email survey techniques (Sekaran and Bougie, 2010).

\subsection{Data collection, population and sampling}

According to Creswell, (2009), there are major two types of research data; primary and secondary research data whereas primary research data is the data collected from different primary sources of data including respondents and secondary data is the data collected from different previously published sources of research data including printed and electronic sources of data. In the research both, the primary and secondary research data have been collected and applied (Cooper and Schindler, 2006). Kasi, (2009), has starts said that for the collection of primary research data, it is necessary to select research population which including all possible sources of primary research data. In the current research, the population group was the people of Mali who are engaged in FDI issue and know about the issue.The major group of population of the research includes economists, university teachers, officials from finance and commerce ministry and officials from foreign affairs ministry of Mali, local investors, foreign investors and officials of World Bank and IMF working in Mali. The research has investigated, 50 sample population have been selected and investigated to collect research data where 5 economists, 10 university teachers, 5 officials from finance and commerce ministry and 5 officials from foreign affairs ministry of Mali, 15 local investors, 5 foreign investors and 5 officials of World Bank and IMF

${ }^{19}$ Plano Clark and Creswell, 2007 
working in Mali. The sample population would be better to be 200 as the more the sample population size will be large more the research data collected from the population will be valid (Sekaran and Bougie, 2010). But due to limited time, the research has investigated 50 samples from the populations. For the selection of the 50 sample population, the non-probability sampling method has been used where the sample population has been selected within a preferable and selective manner.

The reason for applying non-probability sampling method is that within the short span of time, it was impossible to investigate the people selected based on probability method as the method could select such a person who is very difficult to reach (Patton, 2002). For the collection of secondary data for the research, different printed and non-printed sources of secondary research data have been selected and investigated (Mertens \& McLaughlin, 2004). The major sources applied to collect secondary research data of the research included books, journals, magazines, e-books, newspapers, library resources, websites, and blogs (Crowther \& Lancaster, 2008).

\subsection{Data analysis, presentation, ethical consideration and limitation}

Kasi, (2009), has explained that data consistsof unusable forms of research information and these require analyzing and presenting in a valid way to make usable in the research. There are two major ways of data analysis including pre-coding and post-coding system. In the research both the analysis methods have been applied. For the analysis of the numeric or quantitative research data, the pre-coding system has been applied whereas for the analysis of in-depth or qualitative data, the post-coding system has been applied ${ }^{20}$. For the analysis of qualitative data, content analysis tool has been applied whereas for analyzing quantitative data statistical tool, excel has been applied. For the presentation of research data, different tables and charts have been applied. For example, pie chart, bar chart, histograms and radar charts ${ }^{21}$.

Crowther \& Lancaster, (2008), have detailed that for the validity and credibility of a research and research results, it is necessary for conducting the research within ethical ways. For the ethical operation of a research, it is necessary for considering some ethical issues in research operation. For maintaining validity and credibility of research and research results, the major ethical issues have been considered in the research operation are avoidance of plagiarism, ethical collection, storage, analysis and usage of data, maintaining maximum confidentiality of research respondents and research data (Saunders et al., 2009).

Saunders et al., (2007), have detailed that limitations of a research are barriers which restrict to generate perfect research results. In the research, the major limitation is limited time. Within this very limited time such a research may not be produced with maximum perfection which was the major limitation of the research. The next limitation is the small sample size (Gray, \& Guppy, 2007).

\section{CHAPTER-FOUR: DATA ANALYSIS AND PRESENTATION}

For the successful operation of the research, it was necessary to collect research data. In this section of the research, the data collected based on the agreed methodology declared in the previous chapter has been analyzed and presented. In the analysis and presentation of the research, data collected against different research objectives have been arranged in a sequential way as bellow-

\subsection{To investigate the current status of FDI inflow in Mali}

Question-1: Do you agree with the statement that the current FDI inflow to Mali is sufficient to achieve desired economic growth?

\begin{tabular}{|l|l|l|l|l|l|}
\hline \multicolumn{3}{|c|}{} & B. & C. No & D. \\
$\begin{array}{l}\text { Extent } \\
\text { of } \\
\begin{array}{l}\text { Respon } \\
\text { se }\end{array}\end{array}$ & $\begin{array}{l}\text { A. } \\
\text { y } \\
\text { Agreed }\end{array}$ & $\begin{array}{l}\text { Agreed } \\
\text { nt }\end{array}$ & $\begin{array}{l}\text { Disagre } \\
\text { ed }\end{array}$ & $\begin{array}{l}\text { Strong1 } \\
\text { y } \\
\text { Disagre } \\
\text { ed }\end{array}$ \\
\hline $\begin{array}{l}\text { Freque } \\
\text { ncy }\end{array}$ & 0 & 6 & 2 & 30 & 12 \\
\hline $\begin{array}{l}\text { Percen } \\
\text { tage }\end{array}$ & $0 \%$ & $12 \%$ & $4 \%$ & $60 \%$ & $24 \%$ \\
\hline
\end{tabular}

\footnotetext{
${ }^{20}$ Creswell \& Clark, 2007

${ }^{21}$ Cooper and Schindler, 2006
} 


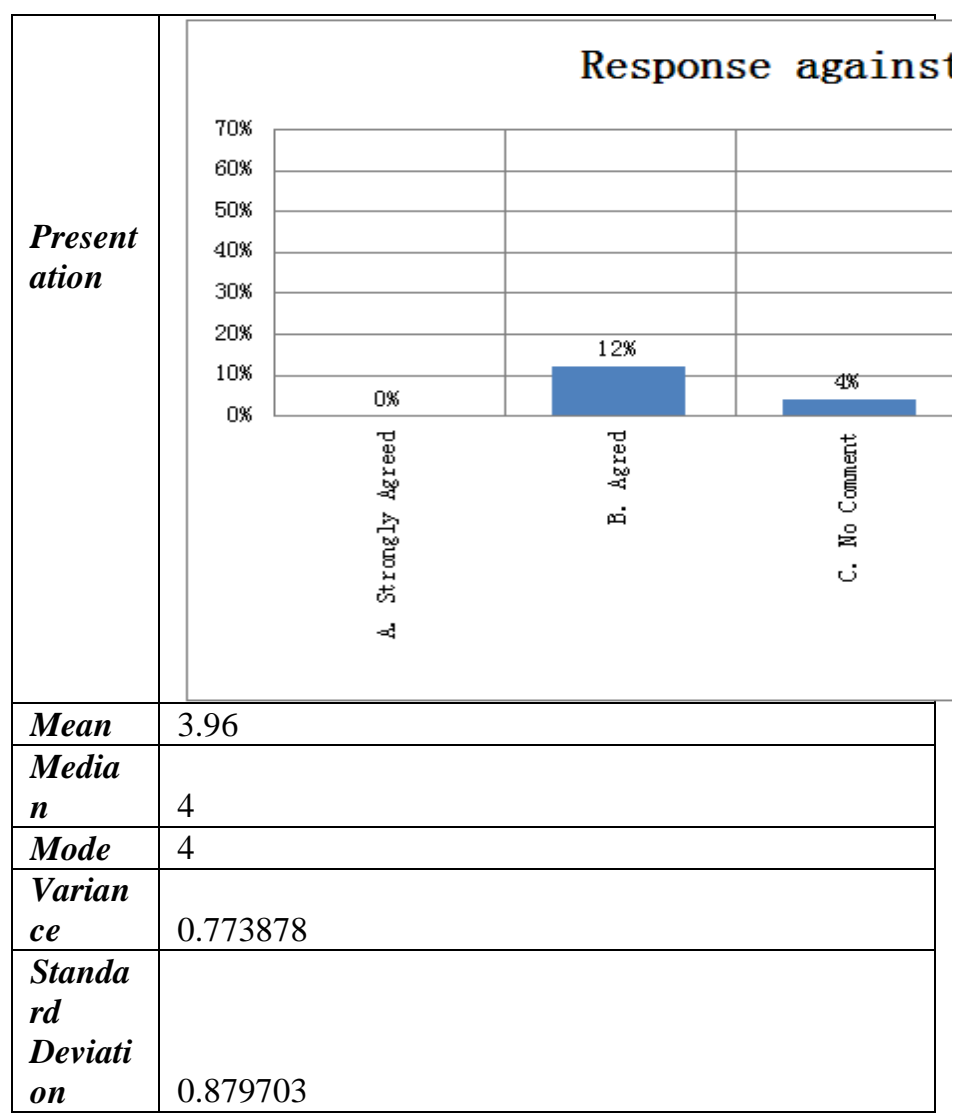

Source: survey questionnaire

From the analysis above, it can be concluded that the current FDI inflow to Mali is insufficient to achieve desired economic growth as $84 \%$, including $60 \%$ moderately and $24 \%$ strongly, of the respondents investigated have supported the position. In contrast, only $6 \%$ of the respondents have opposed the statement. Additionally, $4 \%$ of the respondents have made no comments. The research result has also been supported by statistical analysis as mean, median and mode of responses against the research issue prevails that most of the frequencies investigated lies between disagreed and strongly disagreed points in measurement scale. Additionally, the small standard deviation of 0.879703 declares the validity of the research result. So, as the primary research result regarding the issue, it can be established that the current FDI inflow to Mali is insufficient to achieve desired economic growth.

\subsection{To analyze the impact of FDI on economic growth of Mali}

Question-2: There is a strong relationship between FDI inflow and economic growth in Mali. Do you agree with the statement?

\begin{tabular}{|l|l|l|l|l|l|}
\hline \multicolumn{9}{|c|}{ Data Table-2 } \\
\hline $\begin{array}{l}\text { Extent } \\
\text { of } \\
\begin{array}{l}\text { Respons } \\
\boldsymbol{e}\end{array}\end{array}$ & $\begin{array}{l}\text { A. } \\
\text { Strongly }\end{array}$ & $\begin{array}{l}\text { Agreed } \\
\text { Agreed }\end{array}$ & $\begin{array}{l}\text { C. No } \\
\text { Comment }\end{array}$ & $\begin{array}{l}\text { D. } \\
\text { Disagreed }\end{array}$ & $\begin{array}{l}\text { E. } \\
\text { Strongly } \\
\text { Disagreed }\end{array}$ \\
\hline $\begin{array}{l}\text { Frequen } \\
\text { cy }\end{array}$ & 17 & 26 & 4 & 3 & 0 \\
\hline $\begin{array}{l}\text { Percenta } \\
\text { ge }\end{array}$ & $34 \%$ & $52 \%$ & $8 \%$ & $6 \%$ & $0 \%$ \\
\hline
\end{tabular}




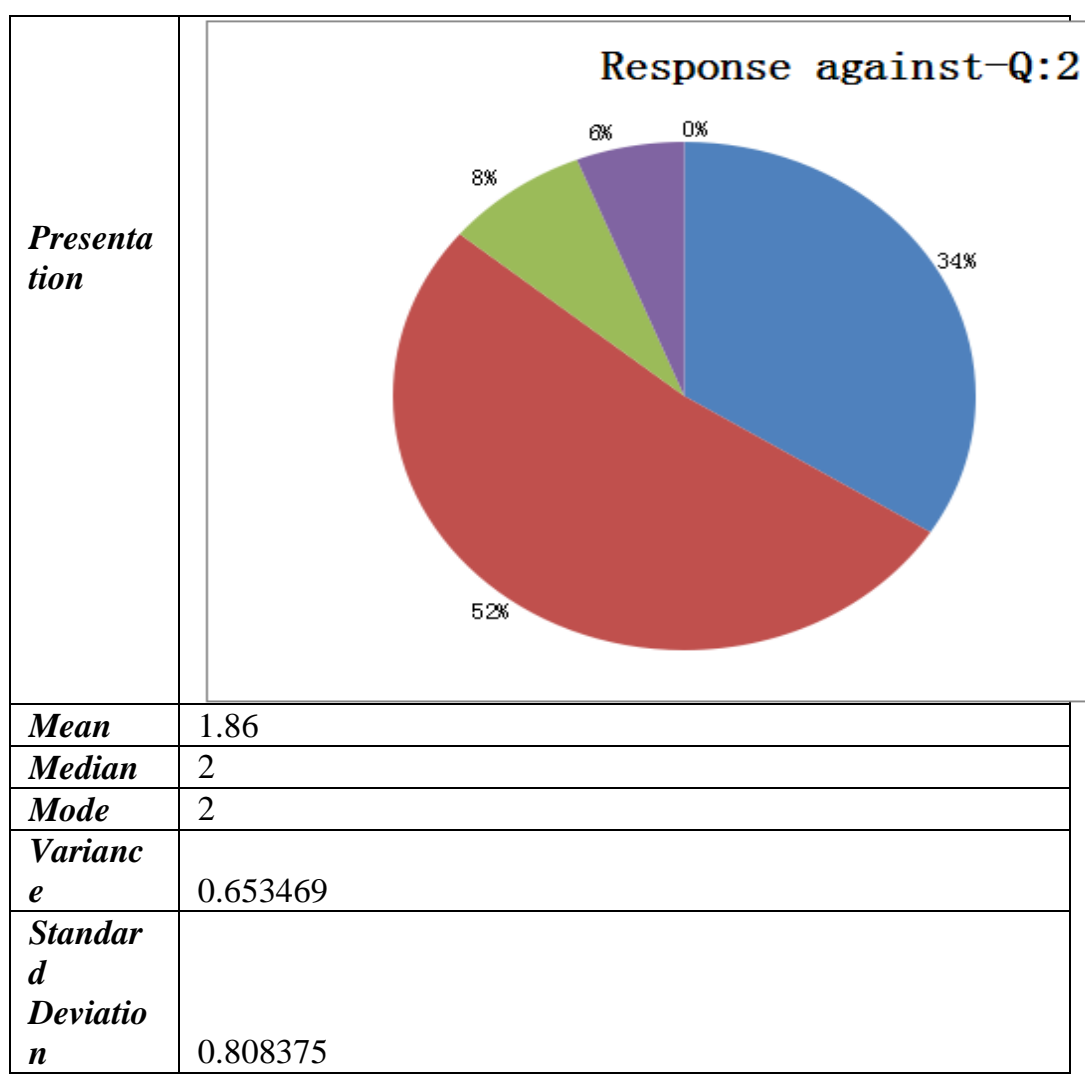

Source: survey questionnaire

From the analysis above, it can be concluded that there is a strong relationship between FDI inflow and economic growth in Mali as $86 \%$, including $52 \%$ moderately and $34 \%$ strongly, of the respondents investigated have supported the position. In contrast, only $6 \%$ of the respondents have opposed the conclusion. Additionally, $8 \%$ of the respondents have made no comments. The research result has also been supported by statistical analysis as mean, median and mode of responses against the research issue prevails that most of the frequencies investigated liesbetween agreed and strongly agreed points in measurement scale. Additionally, the small standard deviation of 0.808375 declares the validity of the research result. So, as the primary research result regarding the issue, it can be established that there is a strong relationship between FDI inflow and economic growth in Mali.

Question-3: The increased inflow of FDI can efficiently enhance economic growth of Mali whereas insufficient inflow of FDI can create strong block against the economic growth of Mali. Do you agree with the statement?

\begin{tabular}{|l|l|l|l|l|l|l|}
\hline \multicolumn{4}{|c|}{ Data Table-3 } \\
\hline $\begin{array}{l}\text { Extent of } \\
\text { Response }\end{array}$ & $\begin{array}{l}\text { A. } \\
\text { Strongly } \\
\text { Agreed }\end{array}$ & $\begin{array}{l}\text { B. } \\
\text { Agreed }\end{array}$ & $\begin{array}{l}\text { C. No } \\
\text { Comment }\end{array}$ & $\begin{array}{l}\text { D. } \\
\text { Disagreed }\end{array}$ & $\begin{array}{l}\text { E. } \\
\text { Strongly } \\
\text { Disagreed }\end{array}$ \\
\hline $\begin{array}{l}\text { Frequen } \\
\text { cy }\end{array}$ & 22 & 25 & 1 & 1 & 1 \\
\hline $\begin{array}{l}\text { Percenta } \\
\text { ge }\end{array}$ & $44 \%$ & $50 \%$ & $2 \%$ & $2 \%$ & $2 \%$ \\
\hline
\end{tabular}




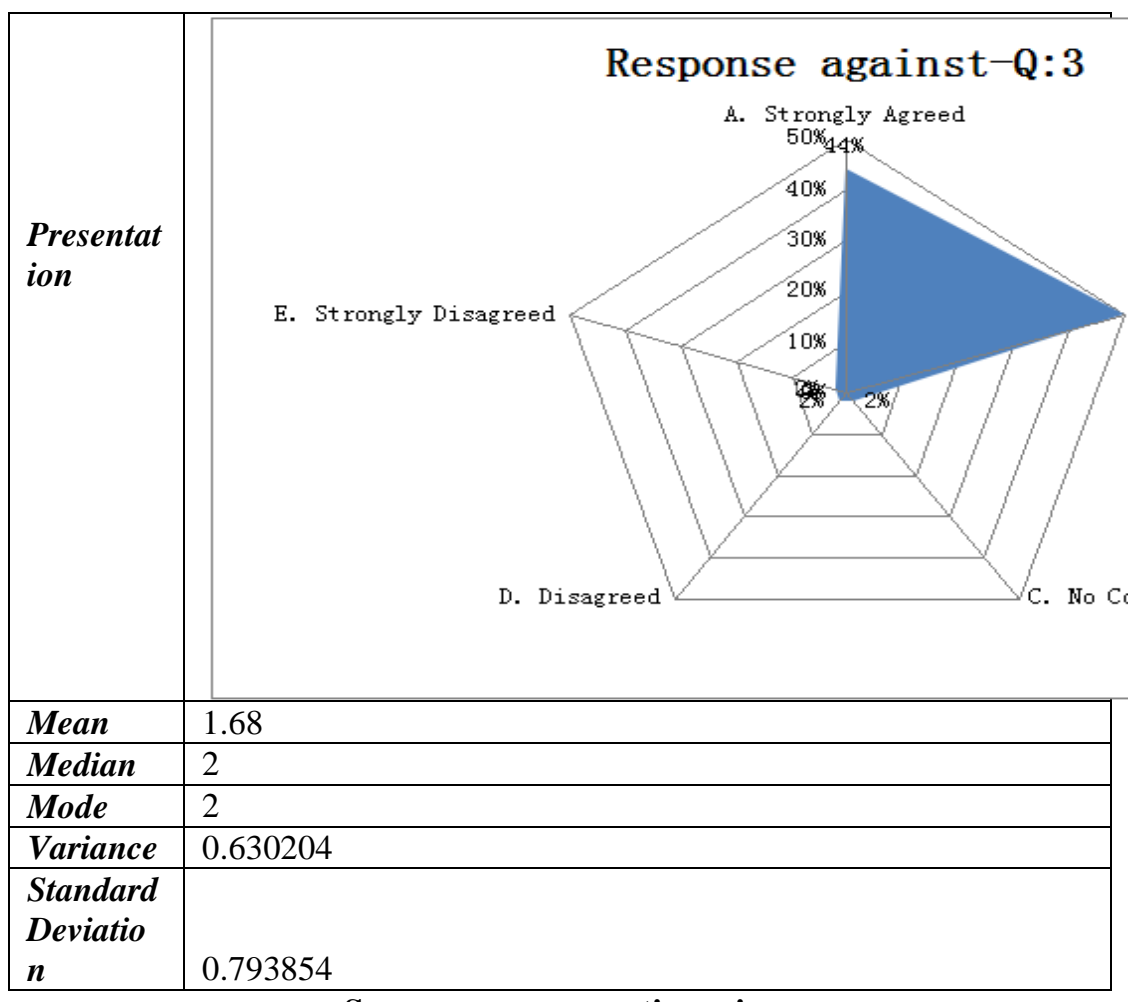

Source: survey questionnaire

From the analysis above, it can be concluded that the increased inflow of FDI can efficiently enhance economic growth of Mali whereas insufficient inflow of FDI can create strong block against the economic growth of Mali as $94 \%$, including $50 \%$ moderately and $44 \%$ strongly, of the respondents investigated have supported the position. In contrast, only $4 \%$ of the respondents have opposed the statement. Additionally, $2 \%$ of the respondents have made nocomments. The research result has also been supported by statistical analysis as mean, median and mode of responses against the research issue prevails that most of the frequencies investigated lies between agreed and strongly agreed points in measurement scale. Additionally, the small standard deviation of 0.793854 declares the validity of the research result. So, as the primary research result regarding the issue, it can be established that the increased inflow of FDI can efficiently enhance economic growth of Mali whereas insufficient inflow of FDI can create strong block against the economic growth of Mali. Question-4: Increased inflow of FDI can enhance the technology transfer to Mali that will contribute to maximize economic productivity and GDP growth as well economic growth of the country. Do you agree with the statement?

\begin{tabular}{|l|l|l|l|l|l|}
\hline Data Table-4 \\
\hline $\begin{array}{l}\text { Extent of } \\
\text { Response }\end{array}$ & $\begin{array}{l}\text { A. Strongly } \\
\text { Agreed }\end{array}$ & B. Agreed & $\begin{array}{l}\text { C. No Dongly } \\
\text { Comment }\end{array}$ & D. Disagreed & $\begin{array}{l}\text { E. Strongly } \\
\text { Disagreed }\end{array}$ \\
\hline Frequency & 27 & 17 & 3 & 2 & 1 \\
\hline Percentage & $54 \%$ & $34 \%$ & $6 \%$ & $4 \%$ & $2 \%$ \\
\hline
\end{tabular}




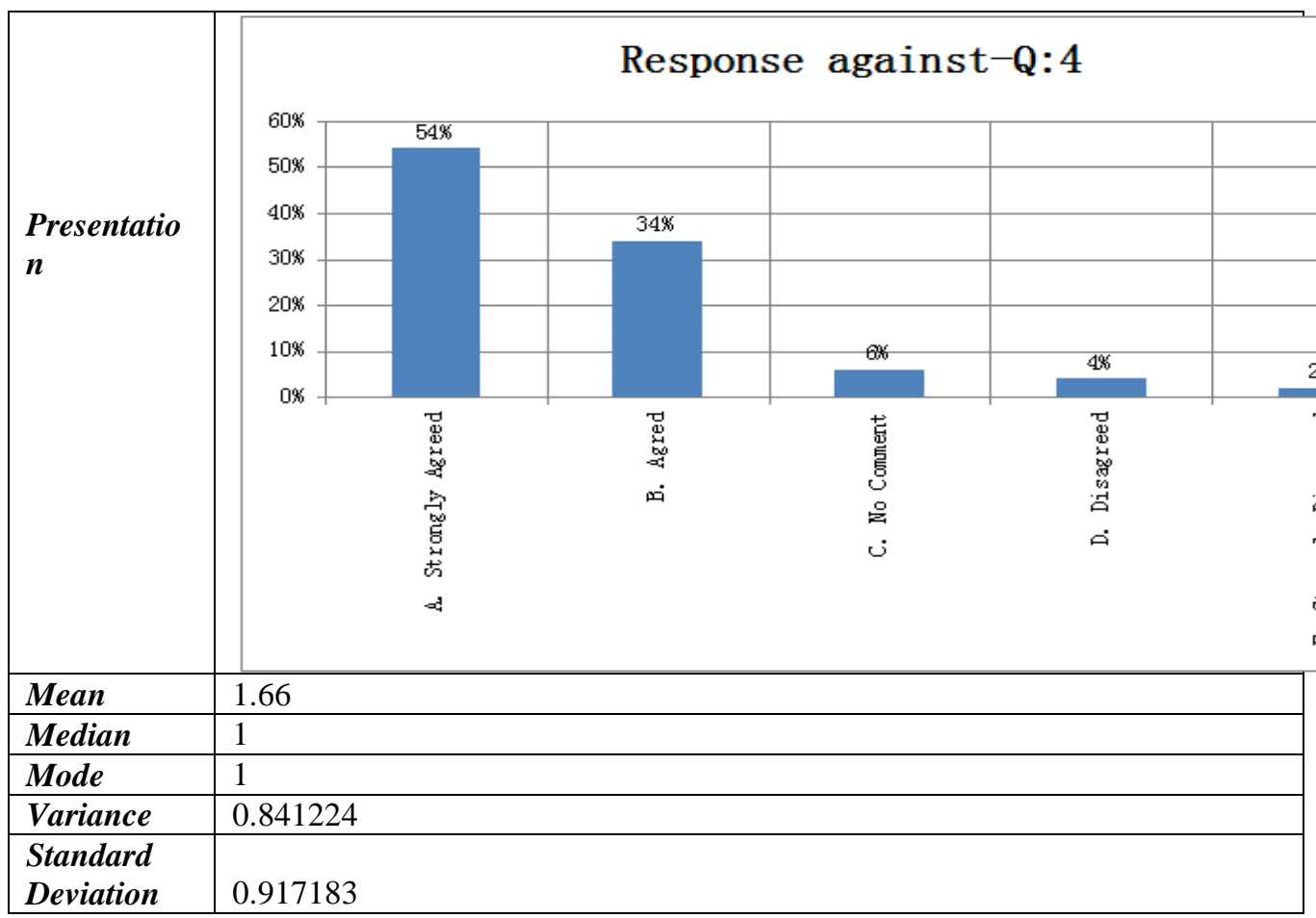

Source: survey questionnaire

From the analysis above, it can be concluded that increased inflow of FDI can enhance the technology transfer to Mali that will contribute to maximize economic productivity and GDP growth as well economic growth of the country as $88 \%$, including $34 \%$ moderately and 54\% strongly, of the respondents investigated have supported the position. In contrast, only $6 \%$ of the respondents have opposed the statement. Additionally, $6 \%$ of the respondents have made no comments. The research result has also been supported by statistical analysis as mean, median and mode of responses against the research issue prevails that most of the frequencies investigated lies between agreed and strongly agreed points in measurement scale. Additionally, the small standard deviation of 0.917183 establishes the validity of the research result. So, as the primary research result regarding the issue, it can be established that increased inflow of FDI can enhance the technology transfer to Mali that will contribute to maximize economic productivity and GDP growth as well economic growth of the country.

Question-5: Do you agree with the statement that high inflow of FDI in Mali can maximize the skills and productivity of its workforce that will actively contribute on economic development and growth of the country?

\begin{tabular}{|l|l|l|l|l|l|}
\hline \multicolumn{7}{|c|}{ Data Table-5 } \\
\hline $\begin{array}{l}\text { Extent of } \\
\text { Response }\end{array}$ & $\begin{array}{l}\text { A. Strongly } \\
\text { Agreed }\end{array}$ & B. Agreed & $\begin{array}{l}\text { C. No } \\
\text { Comment }\end{array}$ & $\begin{array}{l}\text { D. } \\
\text { Disagreed }\end{array}$ & $\begin{array}{l}\text { E. Strongly } \\
\text { Disagreed }\end{array}$ \\
\hline Frequency & 23 & 22 & 1 & 3 & 1 \\
\hline Percentage & $46 \%$ & $44 \%$ & $2 \%$ & $6 \%$ & $2 \%$ \\
\hline
\end{tabular}




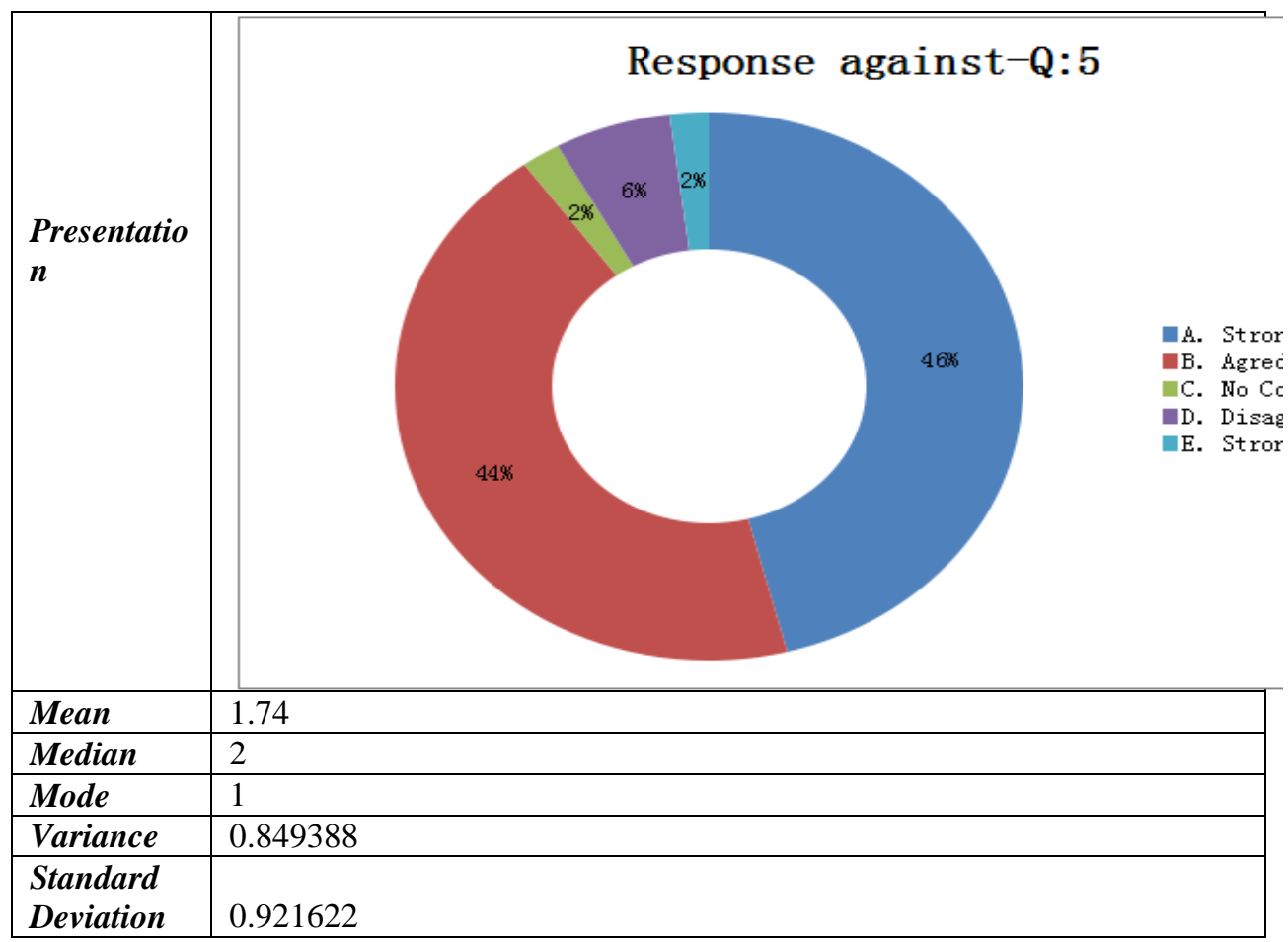

Source: survey questionnaire

From the analysis above, it can be concluded that high inflow of FDI in Mali can maximize the skills and productivity of its workforce that will actively contribute on economic development and growth of the country as $90 \%$, including $44 \%$ moderately and $46 \%$ strongly, of the respondents investigated have supported the position. In contrast, only $8 \%$ of the respondents have opposed the statement. Additionally, $2 \%$ of the respondents have made no comments. The research result has also been supported by statistical analysis as mean, median and mode of responses against the research issue prevails that most of the frequencies investigated lies between agreed and strongly agreed points in measurement scale. Additionally, the small standard deviation of 0.921622 establishes the validity of the research result. So, as the primary research result regarding the issue, it can be established that high inflow of FDI in Mali can maximize the skills and productivity of its workforce that will actively contribute on economic development and growth of the country Question-6: Enhanced inflow of FDI can strengthen the economic growth and development of Mali by enhancing global integration of the economy and reducing the trade imbalance of the country. Are you agree with the statement?

\begin{tabular}{|l|l|l|l|l|l|}
\hline \multicolumn{7}{|c|}{ Data Table-6 } \\
\hline $\begin{array}{l}\text { Extent of } \\
\text { Response }\end{array}$ & $\begin{array}{l}\text { A. Strongly } \\
\text { Agreed }\end{array}$ & B. Agreed & $\begin{array}{l}\text { C. No } \\
\text { Comment }\end{array}$ & D. Disagreed & $\begin{array}{l}\text { E. Strongly } \\
\text { Disagreed }\end{array}$ \\
\hline Frequency & 18 & 24 & 3 & 3 & 2 \\
\hline Percentage & $36 \%$ & $48 \%$ & $6 \%$ & $6 \%$ & $4 \%$ \\
\hline
\end{tabular}




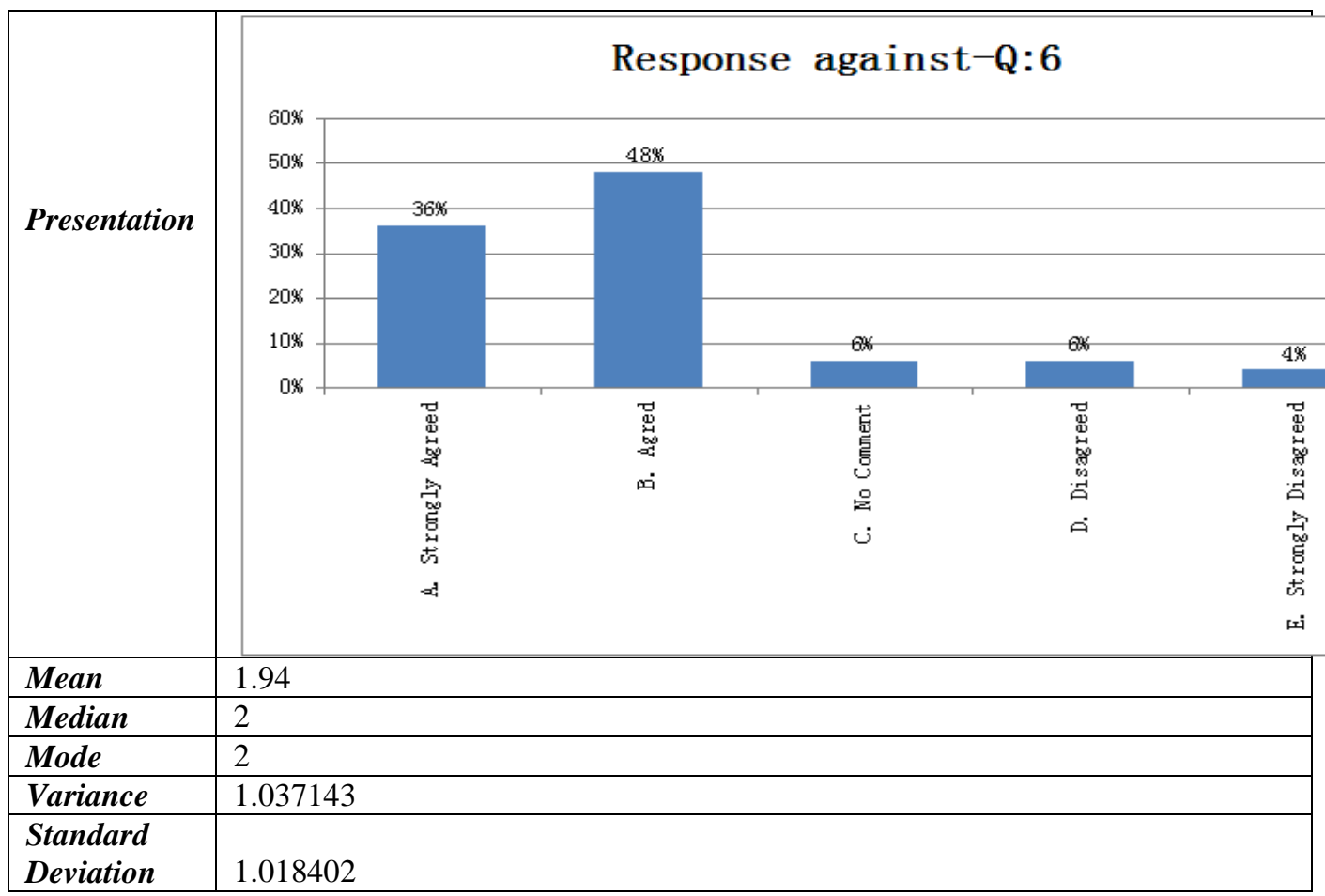

Source: survey questionnaire

From the analysis above, it can be concluded that enhanced inflow of FDI can strengthen the economic growth and development of Mali by enhancing global integration of the economy and reducing the trade imbalance of the country as $84 \%$, including $48 \%$ moderately and $36 \%$ strongly, of the respondents investigated have supported the position. In contrast, only $10 \%$ of the respondents have opposed the statement. Additionally, $6 \%$ of the respondents have made no comments. The research result has also been supported by statistical analysis as mean, median and mode of responses against the research issue prevails that most of the frequencies investigated lies between agreed and strongly agreed points in measurement scale. Additionally, the relatively small standard deviation of 1.018402 establishes the validity of the research result. So, as the primary research result regarding the issue, it can be established that enhanced inflow of FDI can strengthen the economic growth and development of Mali by enhancing global integration of the economy and reducing the trade imbalance of the country.

Question-7: Higher inflow of FDI can maximize the export volume and reduce import volume to ensure desired economic growth in Mali. Do you believe the statement?

\begin{tabular}{|l|l|l|l|l|l|}
\hline \multicolumn{5}{|c|}{ Data Table-7 } \\
\hline $\begin{array}{l}\text { Extent of } \\
\text { Response }\end{array}$ & $\begin{array}{l}\text { A. } \\
\text { Strongly } \\
\text { Agreed }\end{array}$ & B. Agreed & $\begin{array}{l}\text { C. No D. } \\
\text { Comment }\end{array}$ & $\begin{array}{l}\text { D. } \\
\text { Disagreed }\end{array}$ & $\begin{array}{l}\text { Strongly } \\
\text { Disagreed }\end{array}$ \\
\hline $\begin{array}{l}\text { Frequenc } \\
\boldsymbol{y}\end{array}$ & 20 & 23 & 5 & 2 & 0 \\
\hline $\begin{array}{l}\text { Percentag } \\
\boldsymbol{e}\end{array}$ & $40 \%$ & $46 \%$ & $10 \%$ & $4 \%$ & $0 \%$ \\
\hline
\end{tabular}




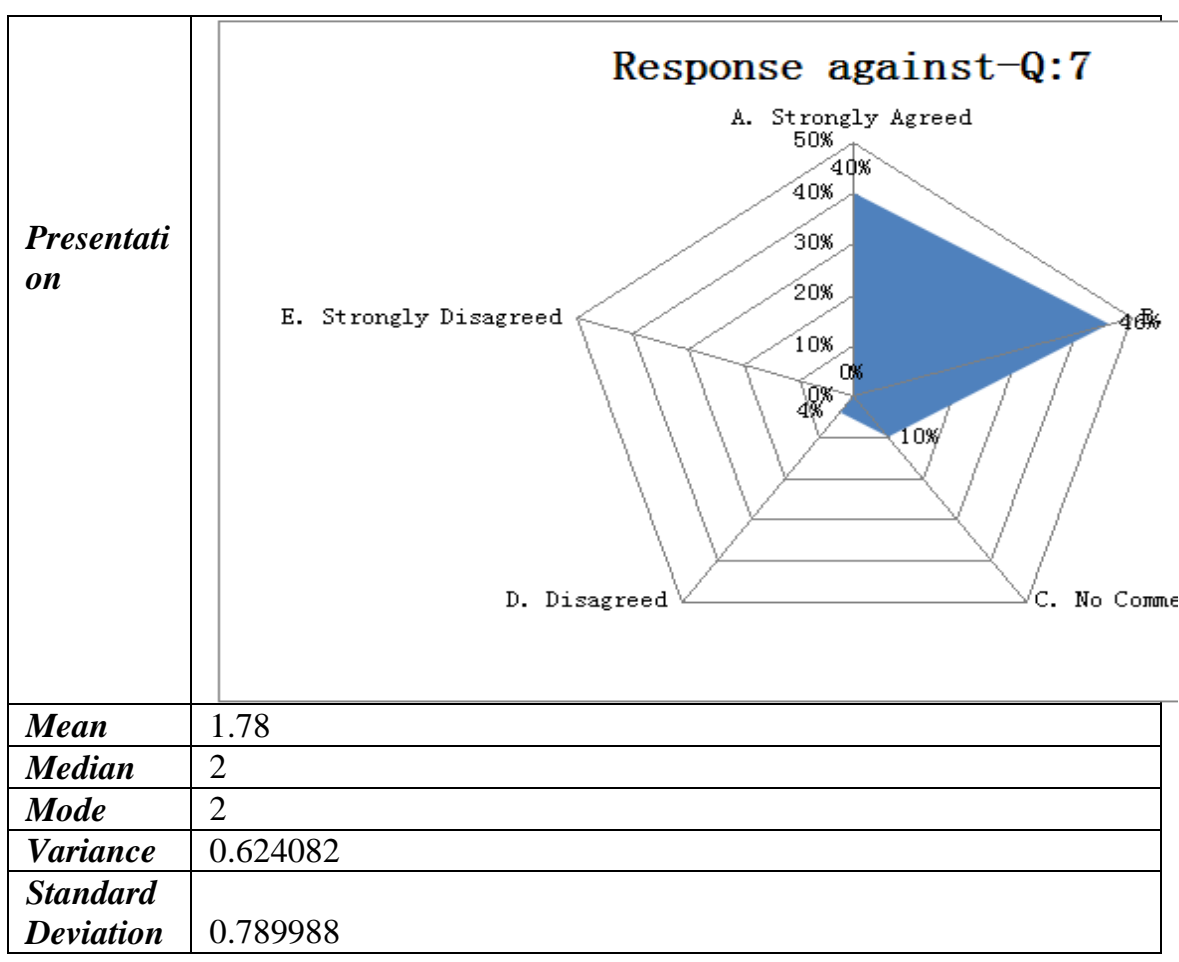

Source : survey questionnaire

From the analysis above, it can be concluded that higher inflow of FDI can maximize the export volume and reduce import volume to ensure desired economic growth in Mali as $86 \%$, including $46 \%$ moderately and $40 \%$ strongly, of the respondents investigated have supported the position. In contrast, only $4 \%$ of the respondents have opposed the statement. Additionally, $10 \%$ of the respondents have made no comments. The research result has also been supported by statistical analysis as mean, median and mode of responses against the research issue prevails that most of the frequencies investigated lies between agreed and strongly agreed points in measurement scale. Additionally, the small standard deviation of 0.789988 establishes the validity of the research result. So, as the primary research result regarding the issue, it can be established that higher inflow of FDI can maximize the export volume and reduce import volume to ensure desired economic growth in Mali.

Question-8: Do you agree that enhanced FDI can actively contribute on the economic growth of Mali by encouraging constructive competition between local and international firms as well maximizing the capacity, productivity and reformation of domestic firms and international business entities?

\begin{tabular}{|l|l|l|l|l|l|}
\hline \multicolumn{5}{|c|}{ Data Table-8 } \\
\hline $\begin{array}{l}\text { Extent of } \\
\text { Response }\end{array}$ & $\begin{array}{l}\text { A. Strongly } \\
\text { Agreed }\end{array}$ & B. Agreed & $\begin{array}{l}\text { C. No } \\
\text { Comment }\end{array}$ & $\begin{array}{l}\text { D. } \\
\text { Disagreed }\end{array}$ & $\begin{array}{l}\text { E. Strongly } \\
\text { Disagreed }\end{array}$ \\
\hline Frequency & 29 & 13 & 1 & 5 & 2 \\
\hline $\begin{array}{l}\text { Percentag } \\
\text { e }\end{array}$ & $58 \%$ & $26 \%$ & $2 \%$ & $10 \%$ & $4 \%$ \\
\hline
\end{tabular}




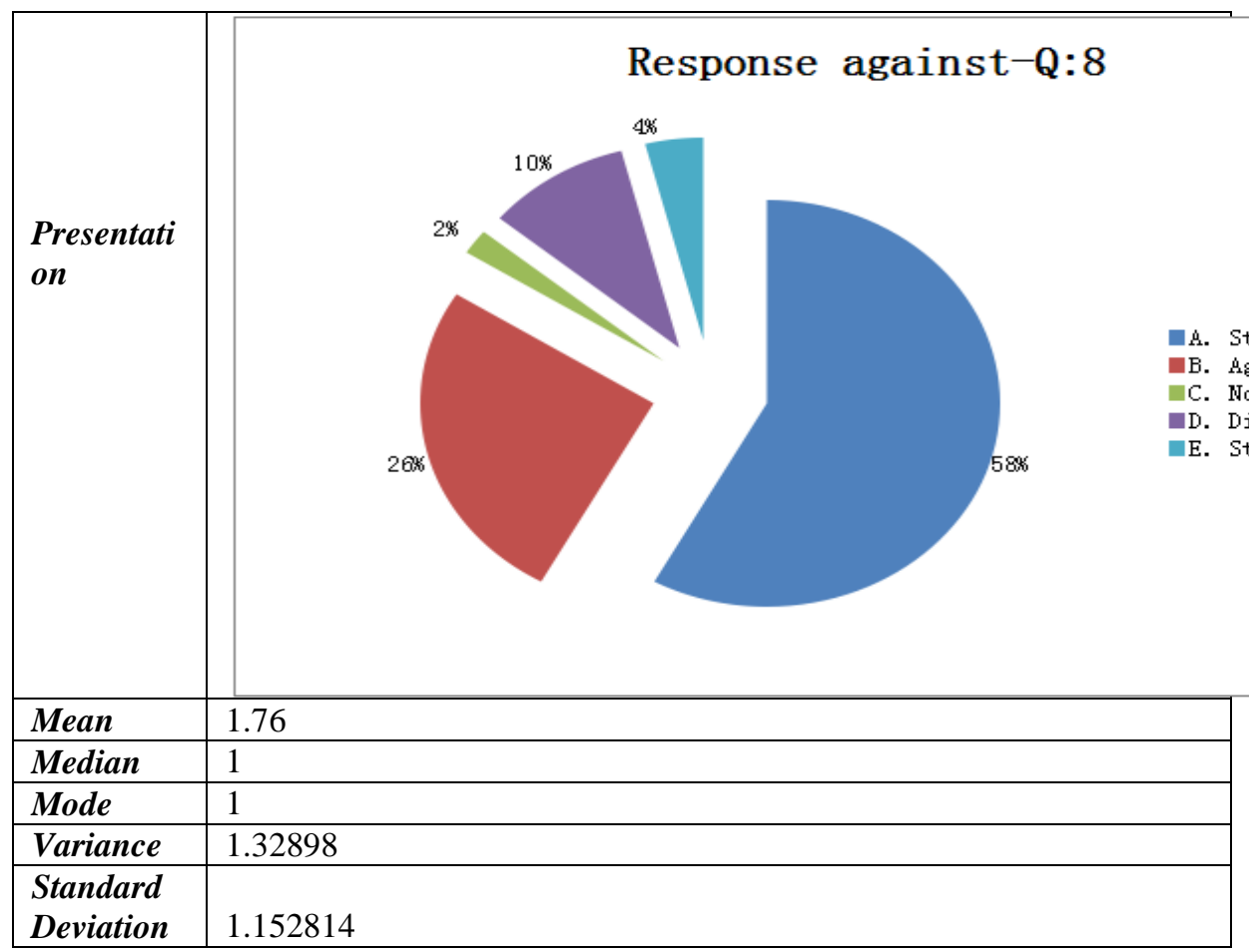

Source: survey questionnaire

From the analysis above, it can be concluded that enhanced FDI can actively contribute on the economic growth of Mali by encouraging constructive competition between local and international firms as well maximizing the capacity, productivity and reformation of domestic firms and international business entities as $84 \%$, including $26 \%$ moderately and $58 \%$ strongly, of the respondents investigated have supported the position. In contrast, only $14 \%$ of the respondents have opposed the statement. Additionally, $2 \%$ of the respondents have made no comments. The research result has also been supported by statistical analysis as mean, median and mode of responses against the research issue prevails that most of the frequencies investigated liesbetween agreed and strongly agreed points in measurement scale. Additionally, relatively small standard deviation of 1.152814 establishes the validity of the research result. So, as the primary research result regarding the issue, it can be established that enhanced FDI can actively contribute on the economic growth of Mali by encouraging constructive competition between local and international firms as well maximizing the capacity, productivity and reformation of domestic firms and international business entities.

\subsection{To assess the barriers of FDIin Mali}

Question-9: How will rate the following factors to attract FDI from the context of Mali?

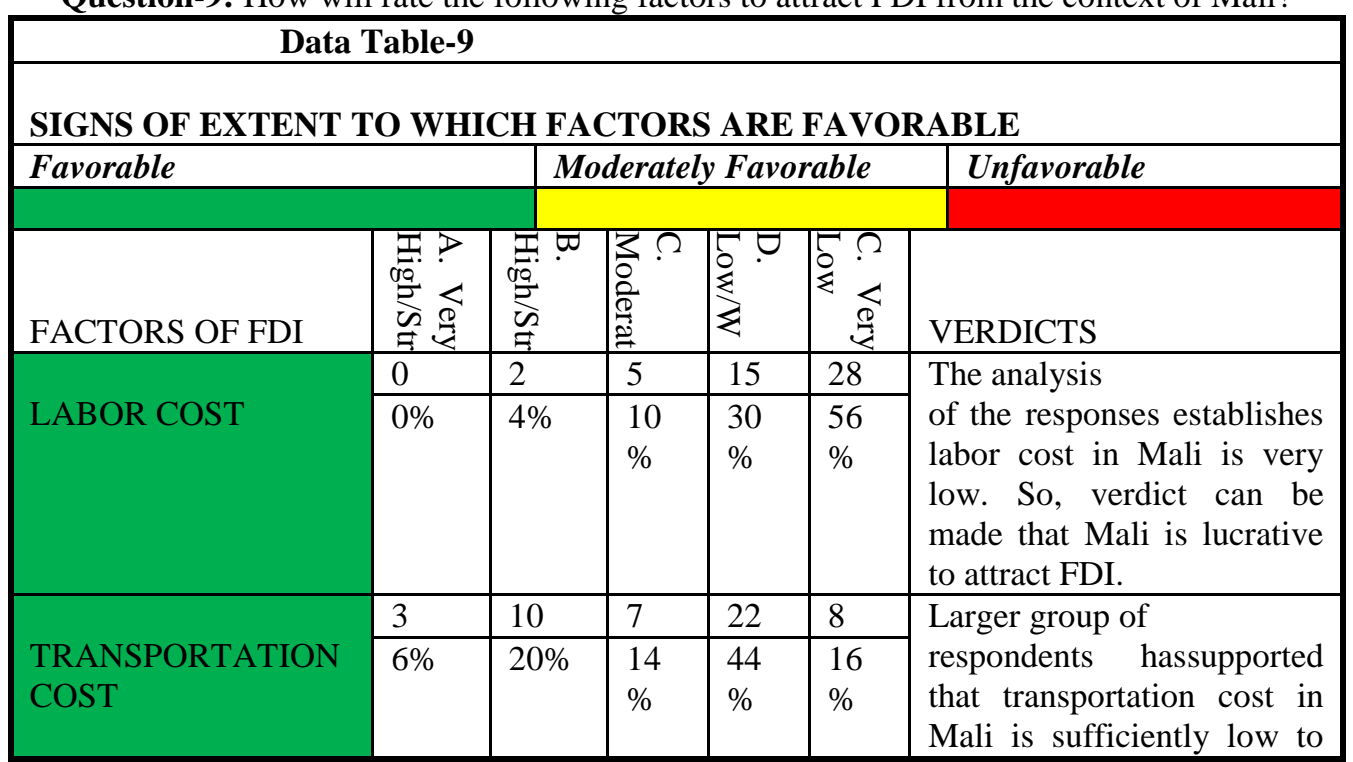




\begin{tabular}{|c|c|c|c|c|c|c|}
\hline & & & & & & attract FDI efficiently. \\
\hline \multirow[b]{2}{*}{$\begin{array}{l}\text { RAW MATERIALS } \\
\text { COST }\end{array}$} & 0 & 3 & 4 & 11 & 32 & \multirow{2}{*}{$\begin{array}{l}\text { The analysis of the data } \\
\text { regarding the issue predicts } \\
\text { that raw materials cost in } \\
\text { Mali is very low that is } \\
\text { highly attractive extent to } \\
\text { achieve high inflow of FDI }\end{array}$} \\
\hline & $0 \%$ & $6 \%$ & $8 \%$ & $\begin{array}{l}22 \\
\%\end{array}$ & $\begin{array}{l}64 \\
\%\end{array}$ & \\
\hline \multirow[b]{2}{*}{$\begin{array}{ll}\text { RETURN } & \text { ON } \\
\text { INVESTMENT }\end{array}$} & 14 & 27 & 3 & 5 & 1 & \multirow{2}{*}{$\begin{array}{l}\text { According to the analysis of } \\
\text { data, return on investment } \\
\text { in Mali is sufficiently high } \\
\text { to attract high inflow of FDI } \\
\text { efficiently. }\end{array}$} \\
\hline & $28 \%$ & $54 \%$ & $6 \%$ & $\begin{array}{l}10 \\
\%\end{array}$ & $2 \%$ & \\
\hline \multirow[b]{2}{*}{$\begin{array}{l}\text { SIZE OF HOST } \\
\text { MARKET }\end{array}$} & 2 & 8 & 20 & 18 & 2 & \multirow[b]{2}{*}{$\begin{array}{l}\text { According to } \\
\text { research data analysis, size } \\
\text { of host market is } \\
\text { moderately large. So, the } \\
\text { verdict can be made that in } \\
\text { case of domestic market } \\
\text { Mali is moderately } \\
\text { attractive. }\end{array}$} \\
\hline & $4 \%$ & $16 \%$ & $\begin{array}{l}40 \\
\%\end{array}$ & $\begin{array}{l}36 \\
\%\end{array}$ & $4 \%$ & \\
\hline \multirow[b]{2}{*}{$\begin{array}{l}\text { LEVEL } \\
\text { COMPETITION }\end{array}$} & 2 & 4 & 5 & 21 & 19 & \multirow[b]{2}{*}{$\begin{array}{l}\text { The data analysis presents } \\
\text { that the level of competition } \\
\text { in Mali is very low. So, } \\
\text { from the context of } \\
\text { competitive environment } \\
\text { Mali is attractive to foreign } \\
\text { investors. }\end{array}$} \\
\hline & $4 \%$ & $8 \%$ & $\begin{array}{l}10 \\
\%\end{array}$ & $\begin{array}{l}42 \\
\%\end{array}$ & $\begin{array}{l}38 \\
\%\end{array}$ & \\
\hline \multirow[b]{2}{*}{$\begin{array}{l}\text { INFRASTRUCTURA } \\
\text { L AND } \\
\text { TECHNOLOGICAL } \\
\text { DEVELOPMENT } \\
\text { LEVEL }\end{array}$} & 0 & 0 & 7 & 26 & 17 & \multirow[b]{2}{*}{$\begin{array}{l}\text { From the analysis } \\
\text { of research response, it has } \\
\text { been prevailed that } \\
\text { infrastructural and } \\
\text { technological development } \\
\text { level is low that is } \\
\text { unattractive to the foreign } \\
\text { investors. }\end{array}$} \\
\hline & $0 \%$ & $0 \%$ & $\begin{array}{l}14 \\
\%\end{array}$ & $\begin{array}{l}52 \\
\%\end{array}$ & $\begin{array}{l}34 \\
\%\end{array}$ & \\
\hline \multirow[b]{2}{*}{$\begin{array}{l}\text { DEVELOPED } \\
\text { HUMAN } \\
\text { RESOURCES } \\
\text { AVAILABILITY } \\
\end{array}$} & 0 & 4 & 10 & 25 & 11 & \multirow[b]{2}{*}{$\begin{array}{l}\text { According to the research } \\
\text { result, the human resource } \\
\text { availability in Mali is very } \\
\text { low that is unattractive for } \\
\text { the foreign investors. }\end{array}$} \\
\hline & $0 \%$ & $8 \%$ & $\begin{array}{l}20 \\
\%\end{array}$ & $\begin{array}{l}50 \\
\%\end{array}$ & $\begin{array}{l}22 \\
\%\end{array}$ & \\
\hline \multirow[b]{2}{*}{$\begin{array}{lr}\text { ACCESS } & \text { TO } \\
\text { RELIABLE AND } \\
\text { COOPERATIVE } \\
\text { SUPPLIERS }\end{array}$} & 0 & 3 & 34 & 10 & 3 & \multirow[b]{2}{*}{$\begin{array}{l}\text { In the light of research } \\
\text { information, it can be } \\
\text { concluded that access to } \\
\text { reliable and cooperative } \\
\text { suppliers in Mali is } \\
\text { moderately attractive. }\end{array}$} \\
\hline & $0 \%$ & $6 \%$ & $\begin{array}{l}68 \\
\%\end{array}$ & $\begin{array}{l}20 \\
\%\end{array}$ & $6 \%$ & \\
\hline \multirow[b]{2}{*}{$\begin{array}{l}\text { POLITICAL } \\
\text { STABILITY }\end{array}$} & 0 & 2 & 8 & 10 & 30 & \multirow{2}{*}{$\begin{array}{l}\text { According to the research } \\
\text { result, the political stability } \\
\text { in Mali is very low that is } \\
\text { unattractive for the foreign } \\
\text { investors. }\end{array}$} \\
\hline & $0 \%$ & $4 \%$ & $\begin{array}{l}16 \\
\%\end{array}$ & $\begin{array}{l}20 \\
\%\end{array}$ & $\begin{array}{l}60 \\
\%\end{array}$ & \\
\hline \multirow[b]{2}{*}{$\begin{array}{l}\text { TAX REDUCTION } \\
\text { OPPORTUNITY }\end{array}$} & 18 & 23 & 5 & 4 & 0 & \multirow[b]{2}{*}{$\begin{array}{l}\text { The data analysis presents } \\
\text { that tax reduction } \\
\text { opportunity in Mali is very } \\
\text { high. So, from the context } \\
\text { of tax reduction } \\
\text { opportunity, Mali is } \\
\text { attractive to foreign }\end{array}$} \\
\hline & $36 \%$ & $46 \%$ & $\begin{array}{l}10 \\
\%\end{array}$ & $8 \%$ & $0 \%$ & \\
\hline
\end{tabular}




\begin{tabular}{|c|c|c|c|c|c|c|}
\hline & & & & & & investors. \\
\hline \multirow[b]{2}{*}{ TRADE BARRIER } & 0 & 2 & 4 & 8 & 36 & \multirow[b]{2}{*}{$\begin{array}{l}\text { The analysis of the data } \\
\text { regarding the issue predicts } \\
\text { that trade barrier in Mali is } \\
\text { very low that is highly } \\
\text { attractive extent to achieve } \\
\text { high inflow of FDI }\end{array}$} \\
\hline & $0 \%$ & $4 \%$ & $8 \%$ & $\begin{array}{l}16 \\
\%\end{array}$ & $\begin{array}{l}72 \\
\%\end{array}$ & \\
\hline \multirow[b]{2}{*}{$\begin{array}{l}\text { ENVIRONMENTAL } \\
\text { LEGISLATION } \\
\text { FLEXIBILITY } \\
\text { LEVEL } \\
\end{array}$} & 15 & 20 & 10 & 3 & 2 & \multirow[b]{2}{*}{$\begin{array}{l}\text { According to the analysis of } \\
\text { data, legislation flexibility } \\
\text { level in Mali is sufficiently } \\
\text { low to attract high inflow of } \\
\text { FDI efficiently. }\end{array}$} \\
\hline & $30 \%$ & $40 \%$ & $\begin{array}{l}20 \\
\%\end{array}$ & $6 \%$ & $4 \%$ & \\
\hline \multirow[b]{2}{*}{$\begin{array}{l}\text { CULTURAL } \\
\text { DISTANCE }\end{array}$} & 0 & 1 & 12 & 29 & 8 & \multirow{2}{*}{$\begin{array}{l}\text { According to the research } \\
\text { result, the cultural distance } \\
\text { in Mali is very low that is } \\
\text { attractive for the foreign } \\
\text { investors. }\end{array}$} \\
\hline & & $2 \%$ & $\begin{array}{l}24 \\
\%\end{array}$ & $\begin{array}{l}58 \\
\%\end{array}$ & $\begin{array}{l}16 \\
\%\end{array}$ & \\
\hline
\end{tabular}

Source: survey questionnaire

Question-10: What are the major barriersand opportunities to ensure desired level ofFDI inflow in Mali?

Most of the respondents have strongly urged that there are huge opportunities to ensure desired level ofFDI inflow in Mali. They have justified their position as Mali has sufficient low costing labor and transportation facilities, enough raw materials supply and low level of domestic competition. They have further explained that the country offers high level of tax reduction opportunities; there are poor level of trade barriers and environmental legislation flexibility level for encouraging foreign investment. Mali was once a colony France which has helped to reduce cultural distance with the western investors. Some of them have said that foreign investors can enjoy the opportunity of quite a big host market and very easy access to reliable and cooperative suppliers, if they invest in Mali.

But at the same time they have warned of some possible barriers to ensure desired level ofFDI inflow in Mali. The major barriers for Mali to attract international investors to enhance FDI inflow are high level of political instability and insecurity for foreign investor groups, insufficient supply of skilled labors, underdeveloped technology andinfrastructures, and insufficiently host market in Mali. Some of the respondents have notified that another major barrier for Mali to be lucrative to foreign investors to enhance high inflow of FDI is the lack of seaports in Mali.

\subsection{To find out possible ways to minimize the barriers to accelerate FDI inflow in Mali.}

Question-11: How to maximizeFDI inflow in Mali to enhance economic growth of Mali?

Most of the respondents have been agreed that Mali has huge business opportunities for the international investors and can ensure huge inflow of FDI, which is the basic need for the country to have desired economic growth. But there are some crucial barriers for the country that will block the maximization ofFDI inflow in Mali to enhance economic growth of the country. According to the response analysis, if the country wants to maximizeFDI inflow in Mali to enhance economic growth of Mali, It should ensure high level of political stability, security for foreign investor groups, and provide sufficient supply of skilled labors . They have further recommended that the country in order to attract desired level of FDI, should significantly reform their infrastructures and transpiration facilities. Some of the respondents have strongly urged that if Mali wants to maximize FDI inflow to enhance economic growth, the country should ensure improvement of the investment code to reassure investors, review and restructure the Customs Code, reassure foreign investors and, most importantly, improve safety for better movement of people and goods. 


\section{CHAPTER-FIVE: DISCUSSION AND EVALUATION}

The discussion and evaluation chapter of the research contains the evaluation of primary research results developed in the previous chapter with the secondary research result developed in literature review. The purpose of the chapter was to validate the primary research results in the light of secondary research findings. In this chapter, for the first time, the primary research results have been detailed and then compared with secondary research results. After that it has been evaluated whether the primary research results are supported by secondary research results to develop research or not.

\subsection{To investigate the current status of FDI inflow in Mali}

From the analysis above, it can be concluded that the current FDI inflow to Mali is insufficient to achieve desired economic growth as $84 \%$, including $60 \%$ moderately and $24 \%$ strongly, of the respondents investigated have supported the position. In contrast, only $6 \%$ of the respondents have opposed the statement. Additionally, $4 \%$ of the respondents have made no comment. The research result has also been supported by statistical analysis as mean, median and mode of responses against the research issue prevails that most of the frequencies investigated lies on between disagreed and strongly disagreed points in measurement scale. Additionally, the small standard deviation of 0.879703 declares the validity of the research result. The FDI inflow in Mali in 2014 was $\$ 410.3$ million which was comparatively lower than any other neighboring sub-Saharan countries like Ivory Coast, Guinea and Senegal. The following figure, collected from the SourceofWorld Bank and given in detail in appendix 4, exposes the inflow of FDI in Mali is lowest in comparison to its neighboring sub-Saharan countries Ivory Coast, Guinea and Senegal. The low trend of FDI inflow in Mali has been continued over the last 14 years. The flowing presentation of World Bank's data proves that there is no gap between the primary findings and secondary findings and agrees that the current FDI inflow to Mali is insufficient to achieve desired economic growth.

Figure 5-1: FDI inflow of Mali, Ivory coast, Guinea and Senegal(2001-2013)

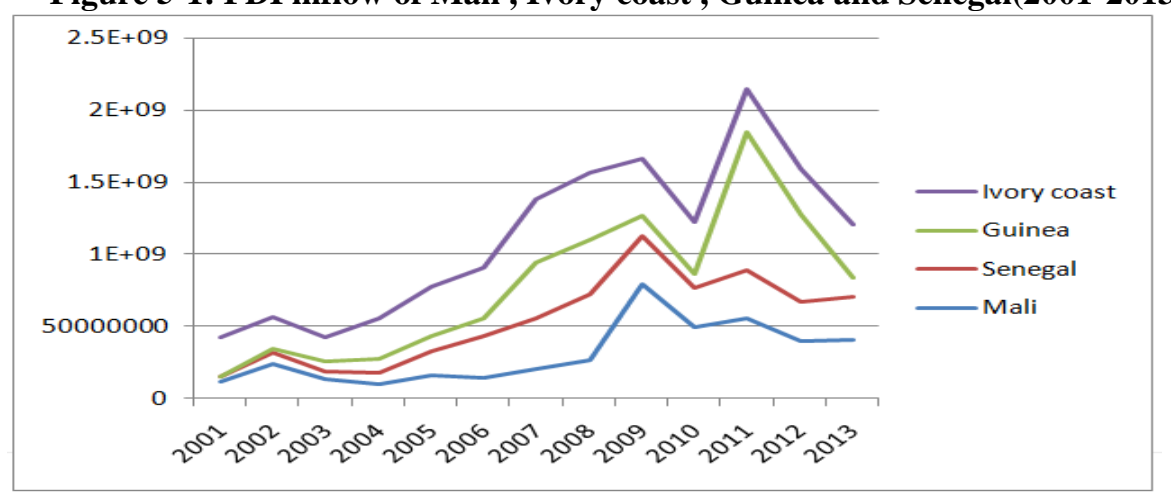

Source: world bank

So, as the primary and secondary research result regarding the issue, it can be established that the current FDI inflow to Mali is insufficient to achieve desired economic growth.

\subsection{To analyze the impact of FDI on economic growth of Mali}

According to the primary research result, there is a strong relationship between FDI inflow and economic growth in Mali and the result has been strengthened by $86 \%$ of the respondents. In contrast, the secondary research results also support the primary research findings as the research of Almfraji and Almsafir, (2014), Sarkar, (2007), Solomon, (2011), Haile \& Assefa, (2006) and Li \& Liu, (2005), have established that there is a strong and significant relationship between FDI and economic growth of developing and underdeveloped countries as the high inflow of FDI strongly accelerate the economic growth of these types of countries whereas the poor FDI inflow in the economy of these countries creates capital shortage that strongly reduces the economic growth from the comparative analysis of primary and secondary research findings that support each other. The data, collected from the World Bank sources and provided in appendix-6, prevails that GDP growth of Mali was $2.1 \%$ in 2013. From the perspective of other neighboring countries like Senegal, Guinea and Ivory Coast, the main economic growth indicator was very low e.g. Ivory Coast gas scored GFO growth of 8.7007774. According to the FDI data presented in appendix -5 presents that in last 13 years Ivory Coast has received more FDI that Mali has strongly contributed to have higher GDP growth. Comparative analysis of FDI inflow and GDP growth prevails during most of those years Ivory Coast received higher inflow of FDI gained higher GDP growth. During those years Ivory Coast received lower inflow of FDI, it faced poor GDP growth for example 2011. 
Figure 5-2: GDP growth of Mali, Ivory coast , Guinea and Senegal( 2001-2013)

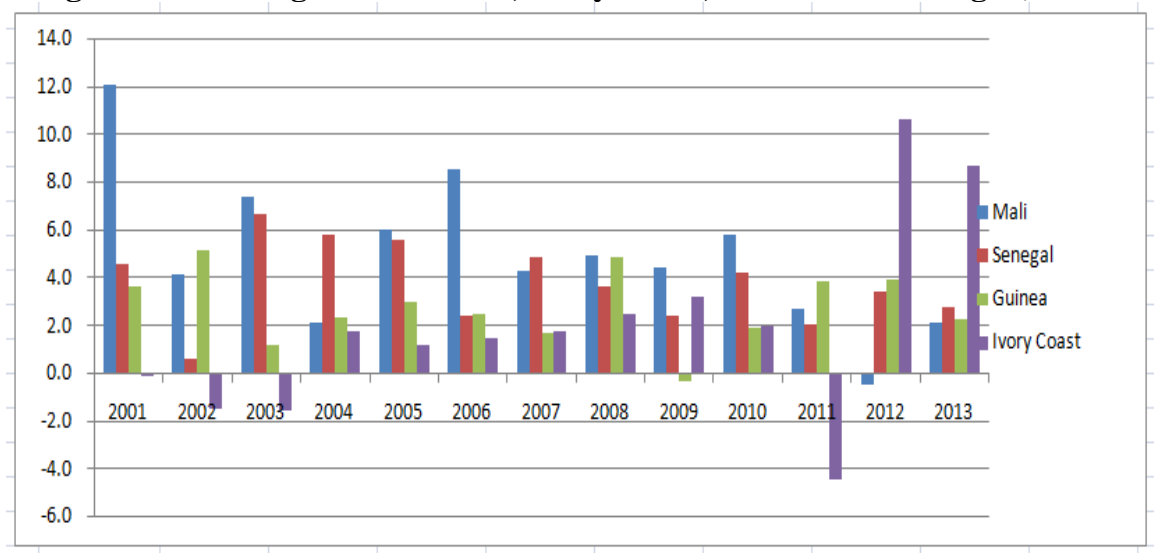

\section{Source: world bank}

So, it can be established as that there is a strong relationship between FDI inflow and economic growth in Mali. Primary research findings have concluded that the increased inflow of FDI can efficiently enhance economic growth of Mali whereas insufficient inflow of FDI can create strong block against the economic growth of Mali. The findings have been generated based on the support of $94 \%$ research respondents. The secondary research findings regarding the research issue strongly support the primary findings as Wacker, (2011) and Baltagi, et al., (2008), (Bhavan et al., 2011) and Azam, (2010) and Hailu, (2010), have revealed that when an underdeveloped country gets high inflow of FDI, the economy can maximize utilization of their resources that maximizes their domestic product. When domestic product becomes higher in volume, it leads the maximization of GDP as well economic growth. In contrast, Zenegnaw, 2010 and Leitão, (2010), have revealed that when an underdeveloped or developing country does not get desired FDI inflow, it cannot support desired capital supply for economic growth that leads poor economic growth. The comparative analysis between primary and secondary findings establishes that the increased inflow of FDI can efficiently enhance economic growth of Mali whereas insufficient inflow of FDI can create strong block against the economic growth of Mali.

From the primary research result, it has been found that increased inflow of FDI can enhance the technology transfer to Mali that will contribute to maximize economic productivity and GDP growth as well economic growth of the country and the research result has been validated by $88 \%$ of the respondents. In the secondary research results, the studies of Almfraji and Almsafir, (2014), Demirhan and Masca, (2008), Bhavan al., (2011), have revealed that the inflow of FDI can efficiently solve the problem of economic productivity within the country as the foreign direct investment enhances the technology transfer which enables the economy in underdeveloped or developing countries to enjoy highly developed technologies that maximize their production. The increased production enhances the economic growth of the countries (Leitão \& Faustino, 2010). In contrast, when an underdeveloped or developing country cannot achieve desired FDI inflow, it loses the opportunity to get developed technology as well increased productivity. In this way; the country cannot achieve desired economic growth (Hanushek and Ludger, 2008). The comparative analysis establishes the research result that increased inflow of FDI can enhance the technology transfer to Mali that will contribute to maximize economic productivity and GDP growth as well economic growth of the country.

Primary research result has established that high inflow of FDI in Mali can maximize the skills and productivity of its workforce that will actively contribute on economic development and growth of the country. The research finding has been generated with the positive responses of $90 \%$ of the respondents investigated. According to the study results of Umoh et al., (2012) and Jadhav, (2012) and Mohamed \& Sidiropoulos, (2010), when FDI inflow increases, foreign investors make significant efforts and invest huge money on human resource development to maximize efficiency of labor force to facilitate their business operation and benefits. These efforts generates a highly skilled labor base for the country that makes direct influence on generating high productivity in economy and ensures higher growth in the economy of developed or underdeveloped countries (Faras \& Ghali, (2009). From the analysis, it can be found that secondary research results do not oppose the primary research finding but support the results strongly. So, it can be established that high inflow of FDI in Mali can maximize the skills and productivity of its workforce that will actively contribute to economic development and growth of the country.

From the primary data analysis, it has been found that enhanced inflow of FDI can strengthen the economic growth and development of Mali by enhancing global integration of the economy and reducing the trade imbalance of the country as $84 \%$ of the respondents have strengthened result. From the secondary research findings, it can be seen that Demirhan and Masca, (2008), Zenegnaw, (2010), Sarkar, (2007), Li \& Liu, (2005) and Castells-Quintana and Royuela, (2012), revealed that developing and underdeveloped countries frequently 
suffer from high level of trade imbalance in case of insufficient international trade integration, less competition and underdeveloped business entities which reduces the economic productivity of the countries. When they get huge inflow of FDI, the economy of the country can reduce the barriers and can maximize their international trade balance, enhance constructive competition between local and international firms and maximize the capacity and productivity of domestic firms and international business entities as well economic growth of the country. From the comparative evaluation and discussion, it has been established that enhanced inflow of FDI can strengthen the economic growth and development of Mali by enhancing global integration of the economy and reducing the trade imbalance of the country.

According to the primary research result, higher inflow of FDI can maximize the export volume and reduce import volume to ensure desired economic growth in Mali. The research result has been validated with $86 \%$ of the respondents investigated. The research results by the studies of Durham, (2004) and Alfaro et al., (2004), have strongly supported the findings as they have found that the increasing inflow of FDI within a country can maximize the integration of domestic economy with global economy that enhances balance between the export and import of the country that efficiently contributes on economic growth of the country. So, the research results can establish that higher inflow of FDI can maximize the export volume and reduce import volume to ensure desired economic growth in Mali.

Primary research result reveals that enhanced FDI can actively contribute to the economic growth of Mali by encouraging constructive competition between local and international firms as well maximizing the capacity, productivity and reformation of domestic firms and international business entities. The research result has been generated from the positive responses of $84 \%$ respondents investigated. According to the studies of Azam, (2010), Bhavan et al., (2011) and Hailu, (2010), when they get huge inflow of FDI, the economy of the country can reduce the barriers and enhance constructive competition between local and international firms and maximize the capacity and productivity of domestic firms and international business entities that will efficiently contribute on economic growth of the host country ( $\mathrm{Li} \& \mathrm{Liu}, 2005)$. So, the primary research result has been supported by secondary research results. In this way; the finding can be established that enhanced FDI can actively contribute on the economic growth of Mali by encouraging constructive competition between local and international firms as well maximizing the capacity, productivity and reformation of domestic firms and international business entities.

\subsection{To assess the barriers of FDI in Mali}

The research has analyzed different factors determining FDI inflow in a country from the context of Mali. Labor cost Mali is lucrative to attract sufficient FDI as it can supply huge low cost labor. Transportation cost in Mali is sufficiently low to attract FDI efficiently. Primary research result supports that raw materials cost in Mali is very low that is highly attractive extent to achieve high inflow of FDI. Return on investment in Mali is sufficiently high to attract high inflow of FDI efficiently. From the context of competitive environment Mali is attractive to foreign investors as competition is very low in host market in the context of tax reduction opportunity, trade barrier, legislation flexibility and cultural distance, Mali is highly attractive for foreign investors as the country has high tax reduction opportunity, low trade barrier, high legislation flexibility and low cultural distance. These will work for Mali as competitive advantages to attract and receive desired level of FDI inflow. But from the context of host market size and reliable and cooperative suppliers, Mali is less attractive to enhance FDI inflow as these factors are in moderate statuses which are not sufficient enough to contribute towards attracting high level of FDI inflow. The factors which can work as the significant weaknesses for Mali to attract and receive desired FDI inflow are high level of political instability, scarcity of skilled human resources and poor infrastructural and technological development. According to the studies of Bhavan et al., (2011), Ang, (2008), Almfraji and Almsafir, (2014) and Schneider \& Matei, (2010), the major factors are economic factors for example cheap labor cost, low transportation or logistic cost, low cost of raw materials, high return on investment; market factors including large size of host markets, high demand in host country and low level of competition; infrastructural factors including high level of infrastructural and technological development, high industrial contraction and high availability of developed human resources. Other most important factors to attract FDI are high access to reliable and cooperative suppliers, high level of political stability, favorable international trade agreement, high tax reduction opportunity, low trade barrier, flexible environmental legislation, favorable social and cultural state, low cultural distance and positive attitudes of local community towards the firm (Almfraji and Almsafir2014) and (Schneider \& Matei, 2010). If a country cannot manage the factors at minimum extent, the country cannot attract high inflow of FDI which can manage the desired and required conditions of these factors can maximize the FDI inflow to its economy to facilitate its economic growth (Bhavan et al., 2011 and Ang, 2008). From the comparative analysis, it has been revealed that Mali can enjoy high level of FDI inflow based on the factors including sufficient low cost labor supply and transportation facilities, abundant less costing raw materials supply, lower level of competition, high level of tax reduction opportunities, poor level of trade barriers, high flexibility of environmental legislation, and limited 
cultural distance with the western investors. But the desired inflow of FDI can be blocked in case of high level of political instability and insecurity for foreign investor groups, insufficient supply of skilled labors, underdeveloped technology and infrastructures, insufficiently big host market and lack of seaports in Mali.

According to the primary researchresult, the major opportunities to ensure desired level ofFDI inflow in Mali are sufficient low cost labor supply and transportation facilities, abundant low cost raw materials supply, lower level of competition, high level of tax reduction opportunities, poor level of trade barriers, high flexibility of environmental legislation, and limited cultural distance with the western investors. From the primary researchresult, it has been revealed that the major barriers for Mali to attract international investors to enhance FDI inflow are high level of political instability and insecurity for foreign investor groups, insufficient supply of skilled labors, underdeveloped technology and infrastructures and insufficiently big host market in Mali. Another major barrier for Mali to be lucrative for foreign investors to enhance high inflow of FDI is the lack of seaports in Mali.

\begin{tabular}{|l|l|}
\hline NO. & $\begin{array}{l}\text { MAJOR BARRIERS TO ACHIEVE HIGH GDP GROWTH IN } \\
\text { MALI }\end{array}$ \\
\hline 1 & High level of political instability \\
\hline 2 & High insecurity for foreign investor groups \\
\hline 3 & Insufficient supply of skilled labors, \\
\hline 4 & Underdeveloped technology and infrastructures \\
\hline 5 & Lack of seaports in Mali \\
\hline 6 & Relatively small host market size \\
\hline 7 & Lack of reliable and cooperative suppliers \\
\hline
\end{tabular}

\subsection{To find out possible ways to minimize the barriers to accelerate FDI inflow in Mali}

In light of primary research result, it can be said thatthere are huge business opportunities for the international investors and can ensure huge inflow of FDI, which is the basic need for the country to have desired economic growth. But, there are some crucial barriers for the country that will block the maximization ofFDI inflow in Mali to enhance economic growth. If the country wants to maximizeFDI inflow in Mali to enhance economic growth, it should ensure high level of political stability and security for foreign investor groups and provide sufficient supply of skilled labors. The country in order to attract desired level of FDI, should significantly reform their infrastructures and transpiration facilities. Additionally, if Mali wants to maximize FDI inflow to enhance economic growth, the country should ensure improve the investment code to reassure investors, review and restructure the Customs Code, reassure foreign investors and, most importantly, improve safety for better movement of people and goods.

\section{CHAPTER-SIX: CONCLUSION AND RECOMMENDATION}

The conclusion and recommendations chapter has been designed to conclude the entire piece of work. In this chapter three major issues have been highlighted and these are conclusion, recommendation and further research grounds. The research has been concluded by comparing research findings with the research objectives. Based on the research results, the recommendations have been developed. At last, the research has investigated possible future research opportunity within this research ground.

\section{VII. $\quad 6.1$ CONCLUSION}

The aim of the research was to investigate the impacts of foreign direct investment (FDI) on economic growth of Mali and to find out ways to achieve desired inflow of FDI in Mali". The research aim has been achieved successfully through the achievement of four specific objectives including (1) to investigate the current status of FDI inflow in Mali, (2) to analyze the impact of FDI on economic growth of Mali, (3) to assess the barriers of FDI in Mali and (4) to find out possible ways to minimize the barriers to accelerate FDI inflow in Mali. The first of objective has been achieved through the analysis and evaluation of research data collected with survey question-1, the second objective has been achieved through the analysis and evaluation of research data collected with survey question- 2 to 8 , third objective has been achieved through the analysis and evaluation of research data collected with survey question- 9 and 10, and finally fourth objective has been achieved through the analysis and evaluation of research data collected with survey question-11. The summary of the research findings are:

Current FDI inflow to Mali is insufficient to achieve desired economic growth. There is a strong relationship between FDI inflow and economic growth in Mali, increased inflow of FDI can efficiently enhance 
economic growth of Mali whereas insufficient inflow of FDI can create strong block against the economic growth of Mali.

The research result that increased inflow of FDI can enhance the technology transfer to Mali that will contribute to maximize economic productivity and GDP growth as well economic growth of the country. High inflow of FDI in Mali can maximize the skills and productivity of its workforce that will actively contribute on economic development and growth of the country. Enhanced inflow of FDI can strengthen the economic growth and development of Mali by enhancing global integration of the economy and reducing the trade imbalance of the country. Higher inflow of FDI can maximize the export volume and reduce import volume to ensure desired economic growth in Mali. Enhanced FDI can actively contribute towards economic growth of Mali by encouraging constructive competition between local and international firms as well maximizing the capacity, productivity and reformation of domestic firms and international business entities.

Mali can enjoy high level of FDI inflow based on the factors including sufficient low cost labor supply and transportation facilities, abundant low cost raw materials supply, lower level of competition, high level of tax reduction opportunities, poor level of trade barriers, high flexibility of environmental legislation, and limited cultural distance with the western investors. But, the desired inflow of FDI can be blocked in case of high level of political instability and insecurity for foreign investor groups, insufficient supply of skilled labors, underdeveloped technology and infrastructures, insufficiently big host market and lack of seaports in Mali. From this context, if the country wants to maximize the FDI inflow to get desired economic growth these issues should be considered and checked carefully by Mali.

Through the research, some possible ways have been found to minimize the barriers to accelerate FDI inflow in Mali. The government of Mali requires ensuring high level of political stability to attract desired level of FDI. If Mali wants to receive high inflow of FDI to accelerate their economic growth, the country must improve their national security system to support foreign investors and their property at a level foreign investors deserve and desire. To attract more and more FDI inflow in Mali, the government of the country should enhance its policies and investment on human resource development as it will convert the abundance of unskilled labor into skilled labor. To attract desired level of FDI, Mali needs to offer developed infrastructures and transportation facilities, flexible investment code to reassure investors, and high level of safety for better movement of people and goods. But, the current research reveals that these factors to attract FDI inflow in Mali are in very weak status. As a result, the research suggests that Mali should significantly reform their infrastructures and transpiration facilities as desired by foreign investors to invest.

\section{6.2 RECOMMENDATIONS}

1. If Mali wants to maximize FDI inflow to enhance economic growth, there is no alternative for the country but removing the crucial barriers resist its FDI inflow because there are huge business opportunities for the international investors and can ensure huge inflow of FDI which is the basic need for the country to have desired economic growth. But, there are some crucial barriers for the country that will block the maximization ofFDI inflow in Mali to enhance economic growth of Mali.

2. The government of Mali must attract more FDI from developed country (manufactures of cotton fabrics, gold processing plant, cement factory ) that will enhance the economics growth of the country.

3. The government of Mali must require to ensure high level of political stability to attract foreign direct investors because the maximization of FDI inflow requires a stable political environment. The reason behind it is that foreign direct investors want to invest their money in a country with high level of political stability.

4. The government must improve their national security system for foreign investors and their property at a level foreign investors deserve and desire because Mali is considered as one of the counties with limited security of foreign investors as the country has some active militant groups. These groups kidnap and seize the people and properties. This insecurity seriously threatens the FDI inflow in Mali as it is the basic requirement to attract larger number of foreign investors.

5. To attract more and more FDI inflow in Mali, the government of the country should enhance its policies and investment on human resource development as it will convert the abundance of unskilled labor into skilled labor. According to the research findings, abundance of skilled human resource supply ensure high inflow of FDI inflow as foreign investors wants to reduce their costs by shifting their business and recruiting low costing labor from developing and underdeveloped countries like Mali. There is a huge supply of low costing labor in Mali; but research findings expose that there is insufficient supply of skilled labor. If the country can do this successfully and efficiently, it will be able to attract more foreign direct investors to ensure high inflow of FDI.

6. According to the research findings, to attract desired level of FDI, Mali needs to offer developed infrastructures and transportation facilities, flexible investment code to reassure investors, and high level of safety for better movement of people and goods. But, the current research reveals that these factors to attract FDI inflow in Mali are in very weak status. As a result, the research suggests that Mali should significantly 
reform their infrastructures and transpiration facilities as desired by foreign investors to invest. Additionally, Mali should ensure improve the investment code to reassure investors, review and restructure the Customs Code, reassure foreign investors and, most importantly, improve safety for better movement of people and goods, if the country wants to maximize FDI inflow to enhance economic growth.

\subsection{Further research ground}

The research has revealed how efficiently and significantly the higher inflow of foreign direct investment (FDI) in Mali can maximize its economic growth. Additionally, the research has carefully and deliberately assessed the barriers to achieve desired FDI inflow to have desired economic growth of Mali. The possible recommendations have been developed for Mali to enhance FDI inflow and economic growth by overcome FDI inflow barriers. But the research has not necessarily developed the ways in which the recommendations to overcome FDI inflow barriers of Mali can be successfully applied to maximize the FDI inflow and economic growth of Mali that has created a fertile future research ground in this research area.

\section{REFERENCE}

[1] Anderson, T., (2010). U.S. affiliates of foreign companies operations in 2008, Survey of Current Business, Vol. 90, No.11, 45-58.

[2] AfDB (2013b). Republic of Mali: Transition management support strategy 2013-2014. African Development Bank

[3] Adewumi, S., (2006). The Impact of FDI on Growth in Developing Countries: An African Experience. [Available at: http://www.diva-portal.org/smash/get/diva2:4440/FULLTEXT01.pdf]. Accessed: 22-032015

[4] Albert, W., \& Brian, D., (2009). Host country corruption level and Foreign Direct Investments inflows International, Journal of Trade and Global Markets, 2(2): 168-178

[5] Asiedu, E., (2005). Foreign Direct Investment in Africa: The Role of Natural Resources, Market Size, Government Policy, Institutions and Political Instability, working paper, United Nations University.

[6] Azam, M. (2010). An Empirical Analysis of the Impacts of Exports and Foreign Direct Investment on Economic Growth in South Asia, Interdisciplinary Journal of Contemporary Research in Business, 2(7)

[7] Ang, J.B., (2008), "Determinants of Foreign Direct Investment in Malaysia," Journal of Policy Modelling, 30 (1), pp. 185-189.

[8] Almfraji, M.A. and Almsafir, M.K., (2014). Foreign Direct Investment and Economic Growth, Procedia - Social and Behavioural Sciences, 129206 - 213

[9] Alfaro, L., et al., (2004). FDI and economic growth: the role of local financial markets, Journal of international economics, 64(1), 89-112.

[10] Al-Iriani, M., (2007). Foreign direct investment and economic growth in the GCC countries: A causality investigation using heterogeneous panel analysis, Topics in Middle Eastern and North African Economies, 9(1), 1-31.

[11] Argyrous, G., and Mongiovi, G (2004) Growth, Distribution, And Effective Demand: Essays in Honor of Edward J. Nell. New York: M.E. Sharpe.

[12] Addison, T. and Baliamoune-Lutz, M., (2006). "Economic Reform When Institutional Quality is Weak: The Case of the Maghreb." Journal of Policy Modeling 28, 1029-1043.

[13] Bhavan, T., et al., (2011). Determinants and Growth Effect of FDI in South Asian Economies: Evidence from a Panel Data Analysis, International Business Research, 4(1)

[14] Boehe, D.M., (2004). Interaction between TNC subsidiaries and the host country innovation system: The case of TNC subsidiaries in Brazil. Universidade Federal do Rio Grande do Sul, School of Management.

[15] Boisvert, M., (2015). Economic Crisis in Mali's North as the South Recovers. [Available at: http://www.ipsnews.net/2014/02/economic-crisis-malis-north-south-recovers/]. Accessed: 22-03-2015

[16] Briceño-Garmendia, C. M., et al., (2011) "Mali's infrastructure: A continental perspective", World Bank Policy Research Working Paper N. 5688, Washington DC

[17] Bair, J., (2005). 'Global Capitalism and Commodity Chains: Looking Back, Going Forward', Competition \& Change, 9(2).

[18] Baltagi, B.H., et al., (2008). 'Estimating regional trade agreement effects on FDI in an interdependent world', Journal of Econometrics, 145(1-2): 194-208

[19] Baxter, M. and Kouparitsas, M. A., (2006). 'What Can Account for Fluctuations in the Terms of Trade?', International Finance, 9: 63-86.

[20] Creswell, J. W., (2009). Research design: Qualitative, quantitative, and mixed methods approaches (3rd ed.). Thousand Oaks, CA: Sage.

[21] Creswell, J. W., (2012). Qualitative inquiry and research design: Choosing among five traditions (3rd ed.). Thousand Oaks, CA: Sage. 
[22] Collins, H., (2011). "Creative Research: The Theory and Practice of Research for the Creative Industries". NY: AVA Publications

[23] Crowther, D. \& Lancaster, G., (2008). "Research Methods: A Concise Introduction to Research in Management and Business Consultancy". NY: Butterworth-Heinemann

[24] Castells-Quintana, D. and Royuela, V., (2012). "Unemployment and long-run economic growth: The role of income inequality and urbanisation". Investigaciones Regionales 12 (24): 153-173

[25] Durham, J.B., (2004). Absorptive capacity and the effects of foreign direct investment and equity foreign portfolio investment on economic growth, European economic review, 48(2), 285-306.

[26] Dellinger, A.B. \& Leech, N.L., (2007). "Toward a Unified Validation Framework in Mixed Methods Research", Journal of Mixed Methods Research; Vol. 1, No. 4, pp. 309-332.

[27] Demirhan, E. and Masca, M., (2008). Determinants of Foreign Direct Investment Flows to Developing Countries: a Cross-Sectional Analysis, Prague economic papers, 4, 2008.

[28] European Union, (2008). Mali - European Community Country Strategy Paper and National Indicative Programme for the period 2008-2013, EU Delegation of the EC in Mali and Ministry for Foreign Affairs and International Cooperation

[29] Ekholm, K., et al., (2007). 'Export Platform Foreign Direct Investment', Journal of the European Economic Association, 5(4): 776-95.

[30] Easterly, W., (2007) "Inequality does cause underdevelopment: Insights from a new instrument" Journal of Development Economics 84(2): 755-776.

[31] Franco, I.E. and Carvalho, I.R.O., (2004). Technological strategies of transnational corporations affiliates in Brazil, Brazilian Administration Review, Vol.1, No.1

[32] Faras, R.Y., \& Ghali, K.H., (2009). Foreign direct investment and economic growth: the case of the GCC countries, International Research Journal of finance and economics, (29), 134-145.

[33] Goedhuys, M., (2007). Learning, product innovation and firm heterogeneity in developing countries: Evidence from Tanzania, Industrial and Corporate Change, Vol. 16, No. 2, pp. 269-292.

[34] Goldsmith, A.A., (2001). "Foreign Aid and Statehood in Africa'. The MIT Press 55.1 (2001): 123-48. J

[35] Galor, O., (2005). From Stagnation to Growth: Unified Growth Theory, Handbook of Economic Growth, Elsevier

[36] Garrett, T.J., (2009). "Are there basic physical constraints on future anthropogenic emissions of carbon dioxide?".Climatic Change 104 (3-4): 437Green, B.N., Johnson, C.D., and Adams, A., (2006). "Writing Narrative Literature Reviews for Peer-Reviewed Journals: Secrets of the Trade", Journal of Chiropractic Medicine; 5(3), pp. 101-114.

[37] Gray, G., \& Guppy, N., (2007). Successful surveys: Research methods and practice (4th ed.). Toronto: Harcourt Canada.

[38] Huffcut, A. I., (2010). From science to practice: Seven principles for conducting employment interviews. Applied H.R.M. Research, 12, 121-136.

[39] Harrison, A. and Rodríguey-Clare, A., (2009). 'Trade, Foreign Investment, and Industrial Policy for Developing Countries', NBER Working Papers, No. 15261

[40] IMF, (2014). Mali at the Dawn of the New Year: From Crisis to Recovery. [Available at: http://www.imf.org/external/np/speeches/2014/010914.htm]. Accessed: 22-03-2015

[41] IMF (2013) Mali - Resuming implementation of the WAEMU harmonized fiscal framework in a postcrisis context, Technical Assistance Report, Fiscal Affairs Department, IMF

[42] Keane, J., et al., (2010). Impediments to intra-regional trade in Sub-Saharan Africa. ODI: London

[43] Leitão, N.C. \& Faustino, H.C., (2010). Determinants of Foreign Direct Investment in Portugal, Journal of Applied Business and Economics, 11(3).

[44] Li, X. \& Liu, X., (2005). Foreign direct investment and economic growth: an increasingly endogenous relationship, World development, 33(3), 393-407

[45] OECD, (2008). Mali. [Available at: http://www.oecd.org/dev/36741457.pdf]. Accessed: 22-03-2015

[46] Oxfam, (2013). "Mali: A new development contract?", Oxfam Briefing Note, May 2013

[47] Patton, M., (2002). Qualitative research and evaluation methods. (3rd ed.). Thousand Oaks, CA: Sage Publications.

[48] Robert, P., (2006). "Democratization in Mali: Putting History to Work," Peace works No. 58, Washington: U.S. Institute of Peace

[49] Schneider, K.H. \& Matei, I., (2010). Business Climate, Political Risk and FDI in Developing Countries: Evidence from Panel Data, International Journal of Economics and Finance, 2(5). 


\section{APPENDIX}

Appendix-1: Sample survey questionnaire

SURVEY QUESTIONNAIRE

Name:

Age:

Gender:

Nationality:

Occupational status:

Sir,

I am studying in School of International Trade and Economics of Jiangxi University of

Finance And Economics in Jiangxi Nanchang, China. I am conducting a research titled

"A critical analysis on the impact of foreign direct investment (FDI) on economic growth of underdeveloped African countries: A case study on Mali" as the fundamental part of academic module to complete my desired degree. The aim of the research is to investigate the impacts of foreign direct investment (FDI) on economic growth of Mali and to find out ways to achieve desired inflow of FDI in Mali. I require your valuable responses to facilitate my data collection tasks for the successful completion of the research. Thank you very much for your kind cooperation.

Question-1: Do you agree with the statement that the current FDI inflow to Mali is sufficient to achieve desired economic growth?

\begin{tabular}{|l|l|l|l|l|}
\hline $\begin{array}{l}\text { A. Strongly } \\
\text { Agreed }\end{array}$ & B. Agreed & C. No Comment & D. Disagreed & $\begin{array}{l}\text { E. Strongly } \\
\text { Disagreed }\end{array}$ \\
\hline & & & & \\
\hline
\end{tabular}

Question-2: There is a strong relationship between FDI inflow and economic growth in Mali. Do you agree with the statement?

\begin{tabular}{|l|l|l|l|l|}
\hline $\begin{array}{l}\text { A. Strongly } \\
\text { Agreed }\end{array}$ & B. Agreed & C. No Comment & D. Disagreed & $\begin{array}{l}\text { E. Strongly } \\
\text { Disagreed }\end{array}$ \\
\hline & & & & \\
\hline
\end{tabular}

Question-3: The increased inflow of FDI can efficiently enhance economic growth of Mali whereas insufficient inflow of FDI can create strong block against the economic growth of Mali. Do you agree with the statement?

\begin{tabular}{|l|l|l|l|l|}
\hline $\begin{array}{l}\text { A. Strongly } \\
\text { Agreed }\end{array}$ & B. Agreed & C. No Comment & D. Disagreed & $\begin{array}{l}\text { E. Strongly } \\
\text { Disagreed }\end{array}$ \\
\hline & & & & \\
\hline
\end{tabular}

Question-4: Increased inflow of FDI can enhance the technology transfer to Mali that will contribute to maximize economic productivity and GDP growth as well economic growth of the country. Do you believe that statement?

\begin{tabular}{|l|l|l|l|l|}
\hline $\begin{array}{l}\text { A. Strongly } \\
\text { Agreed }\end{array}$ & B. Agreed & C. No Comment & D. Disagreed & $\begin{array}{l}\text { E. Strongly } \\
\text { Disagreed }\end{array}$ \\
\hline & & & & \\
\hline
\end{tabular}

Question-5: Do you agree with the statement that high inflow of FDI in Mali can maximize the skills and productivity of its workforce that will actively contribute on economic development and growth of the country?

\begin{tabular}{|l|l|l|l|l|}
\hline $\begin{array}{l}\text { A. Strongly } \\
\text { Agreed }\end{array}$ & B. Agreed & C. No Comment & D. Disagreed & $\begin{array}{l}\text { E. Strongly } \\
\text { Disagreed }\end{array}$ \\
\hline & & & & \\
\hline
\end{tabular}

Question-6: Enhanced inflow of FDI can strengthen the economic growth and development of Mali by enhancing global integration of the economy and reducing the trade imbalance of the country. Are you agreed with the statement?

\begin{tabular}{|l|l|l|l|l|}
\hline $\begin{array}{l}\text { A. Strongly } \\
\text { Agreed }\end{array}$ & B. Agreed & C. No Comment & D. Disagreed & $\begin{array}{l}\text { E. Strongly } \\
\text { Disagreed }\end{array}$ \\
\hline
\end{tabular}




\begin{tabular}{|l|l|l|l|l|}
\hline & & & & \\
\hline
\end{tabular}

Question-7: Higher inflow of FDI can maximize the export volume and reduce import volume to ensure desired economic growth in Mali. Do you believe the statement?

\begin{tabular}{|l|l|l|l|l|}
\hline $\begin{array}{l}\text { A. Strongly } \\
\text { Agreed }\end{array}$ & B. Agreed & C. No Comment & D. Disagreed & $\begin{array}{l}\text { E. Strongly } \\
\text { Disagreed }\end{array}$ \\
\hline & & & & \\
\hline
\end{tabular}

Question-8: Do you agree that enhanced FDI can actively contribute on the economic growth of Mali by encouraging constructive competition between local and international firms as well maximizing the capacity, productivity and reformation of domestic firms and international business entities?

\begin{tabular}{|l|l|l|l|l|}
\hline $\begin{array}{l}\text { A. Strongly } \\
\text { Agreed }\end{array}$ & B. Agreed & C. No Comment & D. Disagreed & $\begin{array}{l}\text { E. Strongly } \\
\text { Disagreed }\end{array}$ \\
\hline & & & & \\
\hline
\end{tabular}

Question-9: How will rate the following factors to attract FDI from the context of Mali?

\begin{tabular}{|l|l|l|l|l|l|}
\hline Factors Of FDI & $\begin{array}{l}\text { A. Very } \\
\text { High/Stro } \\
\text { ng }\end{array}$ & $\begin{array}{l}\text { B. } \\
\text { High/Stro } \\
\text { ng }\end{array}$ & $\begin{array}{l}\text { C. } \\
\text { Moderat } \\
\text { e }\end{array}$ & $\begin{array}{l}\text { D. } \\
\text { Low/We } \\
\text { ek }\end{array}$ & $\begin{array}{l}\text { C. Very } \\
\text { Low } \\
\text { /Week }\end{array}$ \\
\hline Labor cost & & & & & \\
\hline Transportation cost & & & & & \\
\hline Raw materials cost & & & & & \\
\hline $\begin{array}{l}\text { Return } \\
\text { investment }\end{array}$ & & & & & \\
\hline Size of host markets & & & & & \\
\hline Level of competition & & & & & \\
\hline $\begin{array}{l}\text { Infrastructural and } \\
\text { technological } \\
\text { development level }\end{array}$ & & & & & \\
\hline $\begin{array}{l}\text { Developed human } \\
\text { resources } \\
\text { availability }\end{array}$ & & & & & \\
\hline $\begin{array}{l}\text { Access to reliable } \\
\text { and cooperative } \\
\text { suppliers }\end{array}$ & & & & & \\
\hline Political stability & & & & & \\
\hline $\begin{array}{l}\text { Tax reduction } \\
\text { opportunity }\end{array}$ & & & & & \\
\hline Trade barrier & & & & & \\
\hline $\begin{array}{l}\text { Environmental } \\
\text { legislation flexibility } \\
\text { level }\end{array}$ & & & & & \\
\hline Cultural distance & & & & & \\
\hline
\end{tabular}

Question-10: What are the major barriersand opportunities to ensure desired level ofFDI inflow in Mali?

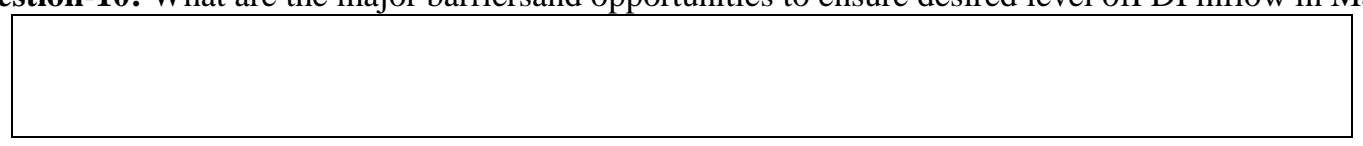

Question-11: How to maximizeFDI inflow in Mali to enhance economic growth of Mali? 


\section{Appendix-2: Sample survey questionnaire (Filled) SURVEY QUESTIONNAIRE \\ Name: \\ Age: \\ Gender: Male \\ Nationality: Malian \\ Occupational status: Mali's Ambassador in China}

Sir,

I am studying in School of International Trade and Economics of Jiangxi University of Finance And Economics in Jiangxi Nanchang, China. I am conducting a research titled "A critical analysis on the impact of foreign direct investment (FDI) on economic growth of underdeveloped African countries: A case study on Mali" as the fundamental part of academic module to complete my desired degree. The aim of the research is to investigate the impacts of foreign direct investment (FDI) on economic growth of Mali and to find out ways to achieve desired inflow of FDI in Mali. I require your valuable responses to facilitate my data collection tasks for the successful completion of the research. Thank you very much for your kind cooperation.

Question-1: Do you agree with the statement that the current FDI inflow to Mali is sufficient to achieve desired

\begin{tabular}{|l|l|l|l|l|}
\hline $\begin{array}{l}\text { A. Strongly } \\
\text { Agreed }\end{array}$ & B. Agreed & C. No Comment & D. Disagreed & $\begin{array}{l}\text { E. Strongly } \\
\text { Disagreed }\end{array}$ \\
\hline & & & $\mathrm{X}$ & \\
\hline
\end{tabular}

Question-2: There is a strong relationship between FDI inflow and economic growth in Mali. Do you agree with the statement?

\begin{tabular}{|l|l|l|l|l|}
\hline $\begin{array}{l}\text { A. Strongly } \\
\text { Agreed }\end{array}$ & B. Agreed & C. No Comment & D. Disagreed & $\begin{array}{l}\text { E. Strongly } \\
\text { Disagreed }\end{array}$ \\
\hline & $\mathrm{X}$ & & & \\
\hline
\end{tabular}

Question-3: The increased inflow of FDI can efficiently enhance economic growth of Mali whereas insufficient inflow of FDI can create strong block against the economic growth of Mali. Do you agree with the statement?

\begin{tabular}{|l|l|l|l|l|}
\hline $\begin{array}{l}\text { A. Strongly } \\
\text { Agreed }\end{array}$ & B. Agreed & C. No Comment & D. Disagreed & $\begin{array}{l}\text { E. Strongly } \\
\text { Disagreed }\end{array}$ \\
\hline & $\mathrm{X}$ & & & \\
\hline
\end{tabular}

Question-4: Increased inflow of FDI can enhance the technology transfer to Mali that will contribute to maximize economic productivity and GDP growth as well economic growth of the country. Do you believe that statement?

\begin{tabular}{|l|l|l|l|l|}
\hline $\begin{array}{l}\text { A. Strongly } \\
\text { Agreed }\end{array}$ & B. Agreed & C. No Comment & D. Disagreed & $\begin{array}{l}\text { E. Strongly } \\
\text { Disagreed }\end{array}$ \\
\hline $\mathrm{X}$ & & & & \\
\hline
\end{tabular}

Question-5: Do you agree with the statement that high inflow of FDI in Mali can maximize the skills and productivity of its workforce that will actively contribute on economic development and growth of the country?

\begin{tabular}{|l|l|l|l|l|}
\hline $\begin{array}{l}\text { A. Strongly } \\
\text { Agreed }\end{array}$ & B. Agreed & C. No Comment & D. Disagreed & $\begin{array}{l}\text { E. Strongly } \\
\text { Disagreed }\end{array}$ \\
\hline $\mathrm{X}$ & & & & \\
\hline
\end{tabular}


Question-6: Enhanced inflow of FDI can strengthen the economic growth and development of Mali by enhancing global integration of the economy and reducing the trade imbalance of the country. Are you agree with the statement?

\begin{tabular}{|l|l|l|l|l|}
\hline $\begin{array}{l}\text { A. Strongly } \\
\text { Agree }\end{array}$ & B. Agree & C. No Comment & D. Disagree & $\begin{array}{l}\text { E. Strongly } \\
\text { Disagree }\end{array}$ \\
\hline & $\mathrm{X}$ & & & \\
\hline
\end{tabular}

Question-7: Higher inflow of FDI can maximize the export volume and reduce import volume to ensure desired economic growth in Mali. Do you believe the statement?

\begin{tabular}{|l|l|l|l|l|}
\hline $\begin{array}{l}\text { A. Strongly } \\
\text { Agree }\end{array}$ & B. Agree & C. No Comment & D. Disagree & $\begin{array}{l}\text { E. Strongly } \\
\text { Disagree }\end{array}$ \\
\hline $\mathrm{X}$ & & & & \\
\hline
\end{tabular}

Question-8: Do you agree that enhanced FDI can actively contribute on the economic growth of Mali by encouraging constructive competition between local and international firms as well maximizing the capacity, productivity and reformation of domestic firms and international business entities?

\begin{tabular}{|l|l|l|l|l|}
\hline $\begin{array}{c}\text { A. Strongly } \\
\text { Agree }\end{array}$ & B. Agree & $\begin{array}{l}\text { C. No } \\
\text { Comment }\end{array}$ & D. Disagree & $\begin{array}{l}\text { E. Strongly } \\
\text { Disagree }\end{array}$ \\
\hline $\mathrm{X}$ & & & & \\
\hline
\end{tabular}

Question-9: How will rate the following factors to attract FDI from the context of Mali?

\begin{tabular}{|c|c|c|c|c|c|}
\hline Factors Of FDI & $\begin{array}{l}\text { A. Very } \\
\text { High/Stro } \\
\text { ng }\end{array}$ & $\begin{array}{l}\text { B. } \\
\text { High/Stro } \\
\text { ng }\end{array}$ & $\begin{array}{l}\text { C. } \\
\text { Moderat } \\
\text { e }\end{array}$ & $\begin{array}{l}\text { D. } \\
\text { Low/Wee } \\
\text { k }\end{array}$ & $\begin{array}{l}\text { C. Very } \\
\text { Low } \\
\text { /Week }\end{array}$ \\
\hline Labor cost & & & $\mathrm{X}$ & & \\
\hline Transportation cost & & & $\mathrm{x}$ & & \\
\hline Raw materials cost & & $\mathrm{X}$ & & & - \\
\hline Return on investment & $\mathrm{X}$ & & & & \\
\hline Size of host markets & & $\mathrm{X}$ & & & \\
\hline Level of competition & & $\mathrm{X}$ & & & \\
\hline $\begin{array}{l}\text { Infrastructure and } \\
\text { technological } \\
\text { development level }\end{array}$ & & $\mathrm{X}$ & & & \\
\hline $\begin{array}{l}\text { Developed human } \\
\text { resources availability }\end{array}$ & $\mathrm{X}$ & & & & \\
\hline $\begin{array}{l}\text { Access to reliable and } \\
\text { cooperative suppliers }\end{array}$ & $\mathrm{X}$ & & & & \\
\hline $\begin{array}{l}\text { Political stability(La } \\
\text { stabilité politique) }\end{array}$ & $\mathrm{X}$ & & & & \\
\hline $\begin{array}{l}\text { Taxreduction } \\
\text { opportunity }\end{array}$ & & $\mathrm{X}$ & & & \\
\hline Trade barrier & & $\mathrm{X}$ & & & \\
\hline $\begin{array}{l}\text { Environmental } \\
\text { legislation flexibility } \\
\text { level }\end{array}$ & & $\mathrm{X}$ & & & \\
\hline Cultural distance & & $\mathrm{X}$ & & & \\
\hline
\end{tabular}


Question-10: What are the major barriersand opportunities to ensure desired level ofFDI inflow in Mali?

\begin{tabular}{|ll|}
\hline- & Lack of seaports \\
- & The skilled labor \\
- & Infrastructure \\
- & The limited local market \\
- & Insecurity \\
\hline
\end{tabular}

Question-11: How to maximizeFDI inflow in Mali to enhance economic growth of Mali?

\begin{tabular}{|ll|}
\hline- & Improve the investment code to reassure investors \\
- & Review the Customs Code \\
- & Improving transport infrastructure \\
- & Improve safety for better movement of people and goods \\
\hline &
\end{tabular}

\begin{tabular}{|c|c|c|c|c|c|c|c|c|c|c|c|}
\hline \multicolumn{12}{|c|}{ Appendix-3: Data summary sheet (Excel) } \\
\hline $\begin{array}{l}\text { Questions } \\
\text { Responden } \\
\text { ts } \\
\end{array}$ & 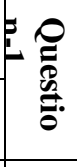 & : & ڤ & \& & 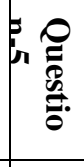 & م & 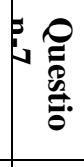 & 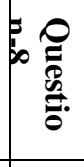 & 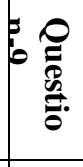 & 象 & 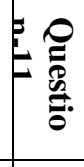 \\
\hline 1 & B & $\mathbf{A}$ & B & D & B & $\mathbf{A}$ & B & $\mathbf{A}$ & & & \\
\hline 2 & D & $\mathbf{B}$ & $\mathbf{A}$ & $\mathbf{B}$ & $\mathbf{A}$ & $\mathbf{B}$ & $\mathbf{A}$ & $\mathbf{D}$ & & & \\
\hline 3 & D & B & B & $\mathbf{A}$ & B & $\mathbf{A}$ & B & B & & & \\
\hline 4 & $\mathbf{E}$ & $\mathbf{C}$ & $\mathbf{A}$ & B & $\mathbf{D}$ & B & $\mathbf{A}$ & $\mathbf{A}$ & & & \\
\hline 5 & $\mathbf{D}$ & $\mathbf{A}$ & $\mathbf{B}$ & $\mathbf{A}$ & $\mathbf{A}$ & $\mathbf{C}$ & B & $\mathbf{E}$ & & & \\
\hline 6 & D & B & $\mathbf{A}$ & B & B & A & B & $\mathbf{A}$ & & & \\
\hline 7 & $\mathbf{E}$ & B & B & $\mathbf{C}$ & $\mathbf{A}$ & B & $\mathbf{A}$ & $\mathbf{A}$ & & & \\
\hline 8 & B & D & $\mathbf{A}$ & $\mathbf{A}$ & B & $\mathbf{A}$ & D & B & & & \\
\hline 9 & C & $\mathbf{A}$ & B & B & $\mathbf{A}$ & B & $\mathbf{A}$ & $\mathbf{A}$ & & & \\
\hline 10 & D & B & $\mathbf{A}$ & $\mathbf{A}$ & B & $\mathbf{A}$ & B & D & & & \\
\hline 11 & D & B & $\mathbf{E}$ & $\mathbf{A}$ & $\mathbf{A}$ & B & $\mathbf{A}$ & $\mathbf{A}$ & & & \\
\hline 12 & D & $\mathbf{A}$ & B & $\mathbf{A}$ & B & C & B & $\mathbf{A}$ & & & \\
\hline 13 & $\mathbf{E}$ & B & $\mathbf{A}$ & B & $\mathbf{A}$ & B & $\mathbf{C}$ & B & & & \\
\hline 14 & D & B & $\mathbf{A}$ & $\mathbf{A}$ & D & $\mathbf{A}$ & $\mathbf{A}$ & $\mathbf{A}$ & & & \\
\hline 15 & B & $\mathbf{A}$ & B & $\mathbf{A}$ & B & D & B & $\mathbf{A}$ & & & \\
\hline 16 & D & B & $\mathbf{A}$ & B & $\mathbf{A}$ & B & $\mathbf{A}$ & B & & & \\
\hline 17 & D & B & B & $\mathbf{A}$ & $\mathbf{A}$ & $\mathbf{A}$ & B & $\mathbf{A}$ & & & \\
\hline 18 & $\mathbf{E}$ & B & $\mathbf{A}$ & $\mathbf{A}$ & B & B & $\mathbf{A}$ & B & & & \\
\hline 19 & D & $\mathbf{A}$ & B & B & $\mathbf{A}$ & $\mathbf{A}$ & B & $\mathbf{A}$ & & & \\
\hline 20 & D & $\mathbf{C}$ & $\mathbf{A}$ & $\mathbf{A}$ & B & B & $\mathbf{A}$ & D & & & \\
\hline 21 & D & B & B & B & $\mathbf{E}$ & A & C & B & & & \\
\hline 22 & D & $\mathbf{A}$ & $\mathbf{A}$ & $\mathbf{A}$ & $\mathbf{A}$ & B & $\mathbf{A}$ & $\mathbf{A}$ & & & \\
\hline 23 & D & B & B & B & $\mathbf{A}$ & $\mathbf{A}$ & B & $\mathbf{A}$ & & & \\
\hline 24 & $\mathbf{E}$ & B & $\mathbf{A}$ & $\mathbf{A}$ & B & B & $\mathbf{A}$ & B & & & \\
\hline 25 & D & $\mathbf{A}$ & B & $\mathbf{E}$ & $\mathbf{A}$ & $\mathbf{A}$ & B & $\mathbf{A}$ & & & \\
\hline 26 & B & D & $\mathbf{A}$ & $\mathbf{A}$ & B & B & $\mathbf{A}$ & B & & & \\
\hline 27 & D & $\mathbf{A}$ & B & B & B & A & B & $\mathbf{A}$ & & & \\
\hline 28 & D & B & D & $\mathbf{A}$ & B & B & $\mathbf{A}$ & B & & & \\
\hline 29 & $\mathbf{E}$ & B & $\mathbf{A}$ & $\mathbf{A}$ & $\mathbf{A}$ & $\mathbf{E}$ & B & $\mathbf{A}$ & & & \\
\hline 30 & D & $\mathbf{A}$ & B & $\mathbf{A}$ & $\mathbf{A}$ & $\mathbf{A}$ & $\mathbf{A}$ & $\mathbf{A}$ & & & \\
\hline 31 & $\mathbf{E}$ & B & B & $\mathbf{C}$ & B & D & B & $\mathbf{A}$ & & & \\
\hline 32 & D & B & $\mathbf{A}$ & B & $\mathbf{A}$ & B & $\mathbf{C}$ & $\mathbf{A}$ & & & \\
\hline 33 & D & $\mathbf{A}$ & B & D & B & $\mathbf{A}$ & B & $\mathbf{A}$ & & & \\
\hline
\end{tabular}




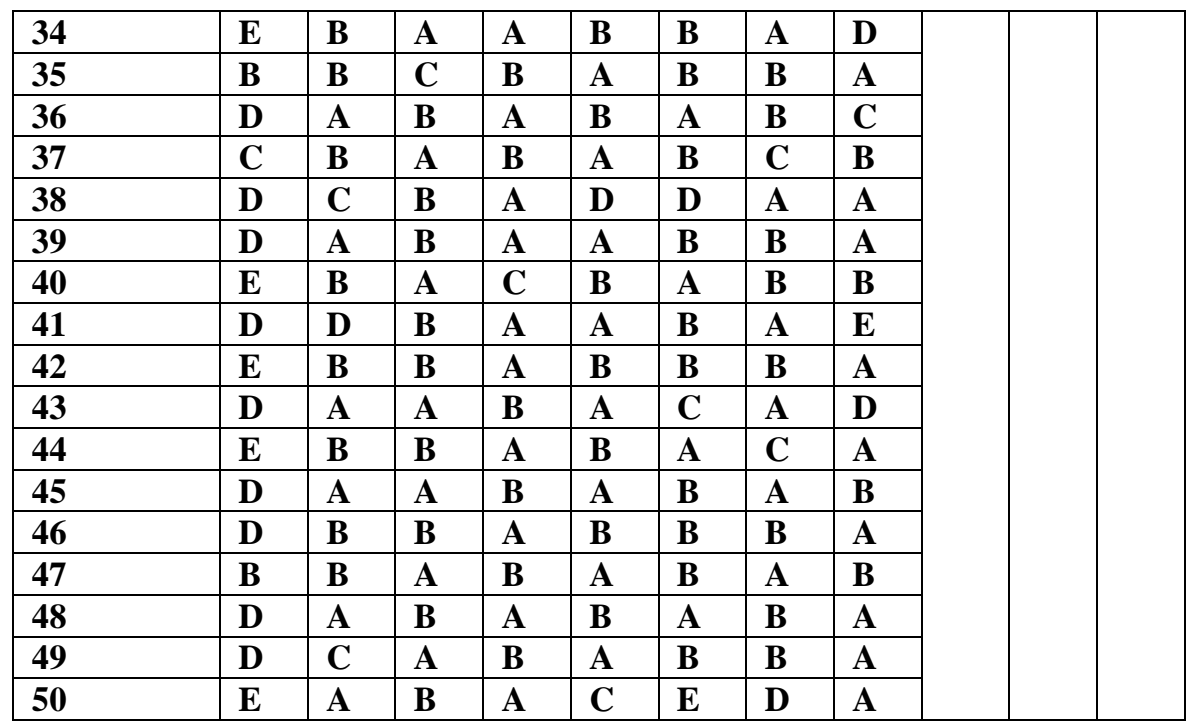

Appendix-4: Statistical data analysis summary

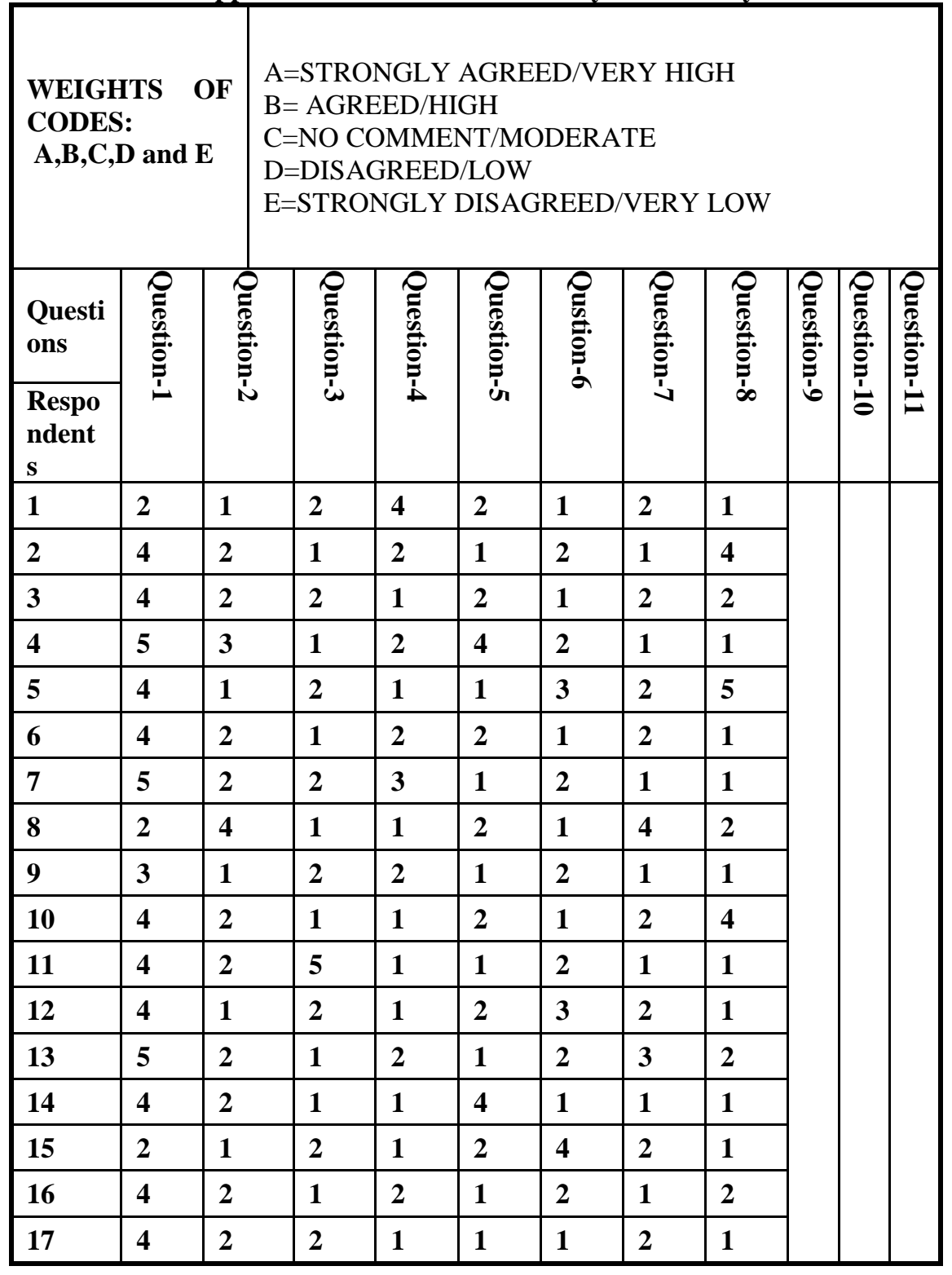




\begin{tabular}{|c|c|c|c|c|c|c|c|c|}
\hline 18 & 5 & 2 & 1 & 1 & 2 & 2 & 1 & 2 \\
\hline 19 & 4 & 1 & 2 & 2 & 1 & 1 & 2 & 1 \\
\hline 20 & 4 & 3 & 1 & 1 & 2 & 2 & 1 & 4 \\
\hline 21 & 4 & 2 & 2 & 2 & 5 & 1 & 3 & 2 \\
\hline 22 & 4 & 1 & 1 & 1 & 1 & 2 & 1 & 1 \\
\hline 23 & 4 & 2 & 2 & 2 & 1 & 1 & 2 & 1 \\
\hline 24 & 5 & 2 & 1 & 1 & 2 & 2 & 1 & 2 \\
\hline 25 & 4 & 1 & 2 & 5 & 1 & 1 & 2 & 1 \\
\hline 26 & 2 & 4 & 1 & 1 & 2 & 2 & 1 & 2 \\
\hline 27 & 4 & 1 & 2 & 2 & 2 & 1 & 2 & 1 \\
\hline 28 & 4 & 2 & 4 & 1 & 2 & 2 & 1 & 2 \\
\hline 29 & 5 & 2 & 1 & 1 & 1 & 5 & 2 & 1 \\
\hline 30 & 4 & 1 & 2 & 1 & 1 & 1 & 1 & 1 \\
\hline 31 & 5 & 2 & 2 & 3 & 2 & 4 & 2 & 1 \\
\hline 32 & 4 & 2 & 1 & 2 & 1 & 2 & 3 & 1 \\
\hline 33 & 4 & 1 & 2 & 4 & 2 & 1 & 2 & 1 \\
\hline 34 & 5 & 2 & 1 & 1 & 2 & 2 & 1 & 4 \\
\hline 35 & 2 & 2 & 3 & 2 & 1 & 2 & 2 & 1 \\
\hline 36 & 4 & 1 & 2 & 1 & 2 & 1 & 2 & 3 \\
\hline 37 & 3 & 2 & 1 & 2 & 1 & 2 & 3 & 2 \\
\hline 38 & 4 & 3 & 2 & 1 & 4 & 4 & 1 & 1 \\
\hline 39 & 4 & 1 & 2 & 1 & 1 & 2 & 2 & 1 \\
\hline 40 & 5 & 2 & 1 & 3 & 2 & 1 & 2 & 2 \\
\hline 41 & 4 & 4 & 2 & 1 & 1 & 2 & 1 & 5 \\
\hline 42 & 5 & 2 & 2 & 1 & 2 & 2 & 2 & 1 \\
\hline 43 & 4 & 1 & 1 & 2 & 1 & 3 & 1 & 4 \\
\hline 44 & 5 & 2 & 2 & 1 & 2 & 1 & 3 & 1 \\
\hline 45 & 4 & 1 & 1 & 2 & 1 & 2 & 1 & 2 \\
\hline 46 & 4 & 2 & 2 & 1 & 2 & 2 & 2 & 1 \\
\hline 47 & 2 & 2 & 1 & 2 & 1 & 2 & 1 & 2 \\
\hline 48 & 4 & 1 & 2 & 1 & 2 & 1 & 2 & 1 \\
\hline 49 & 4 & 3 & 1 & 2 & 1 & 2 & 2 & 1 \\
\hline 50 & 5 & 1 & 2 & 1 & 3 & 5 & 4 & 1 \\
\hline Mean & 3.96 & 1.86 & 1.68 & 1.66 & 1.74 & 1.94 & 1.78 & 1.76 \\
\hline $\begin{array}{l}\text { Media } \\
\mathrm{n}\end{array}$ & 4 & 2 & 2 & 1 & 2 & 2 & 2 & 1 \\
\hline Mode & 4 & 2 & 2 & 1 & 1 & 2 & 2 & 1 \\
\hline $\begin{array}{l}\text { Varian } \\
\text { ce }\end{array}$ & $\begin{array}{l}0.77 \\
387 \\
8 \\
\end{array}$ & $\begin{array}{l}0.65 \\
3469 \\
\end{array}$ & $\begin{array}{l}0.63 \\
020 \\
4 \\
\end{array}$ & $\begin{array}{l}0.84 \\
122 \\
4 \\
\end{array}$ & $\begin{array}{l}0.84 \\
938 \\
8 \\
\end{array}$ & $\begin{array}{l}1.03 \\
714 \\
3 \\
\end{array}$ & $\begin{array}{l}0.62 \\
408 \\
2 \\
\end{array}$ & $\begin{array}{l}1.32 \\
898 \\
\end{array}$ \\
\hline $\begin{array}{l}\text { Standa } \\
\text { rd } \\
\text { deviati } \\
\text { on }\end{array}$ & $\begin{array}{l}0.87 \\
970 \\
3\end{array}$ & $\begin{array}{l}0.80 \\
8375\end{array}$ & $\begin{array}{l}0.79 \\
385 \\
4\end{array}$ & $\begin{array}{l}0.91 \\
718 \\
3\end{array}$ & $\begin{array}{l}0.92 \\
162 \\
2 \\
\end{array}$ & $\begin{array}{l}1.01 \\
840 \\
2\end{array}$ & $\begin{array}{l}0.78 \\
998 \\
8\end{array}$ & $\begin{array}{l}1.15 \\
281 \\
4\end{array}$ \\
\hline
\end{tabular}


Appendix-5: Comparative analysis of FDI inflow in Mali and its neighboring countries

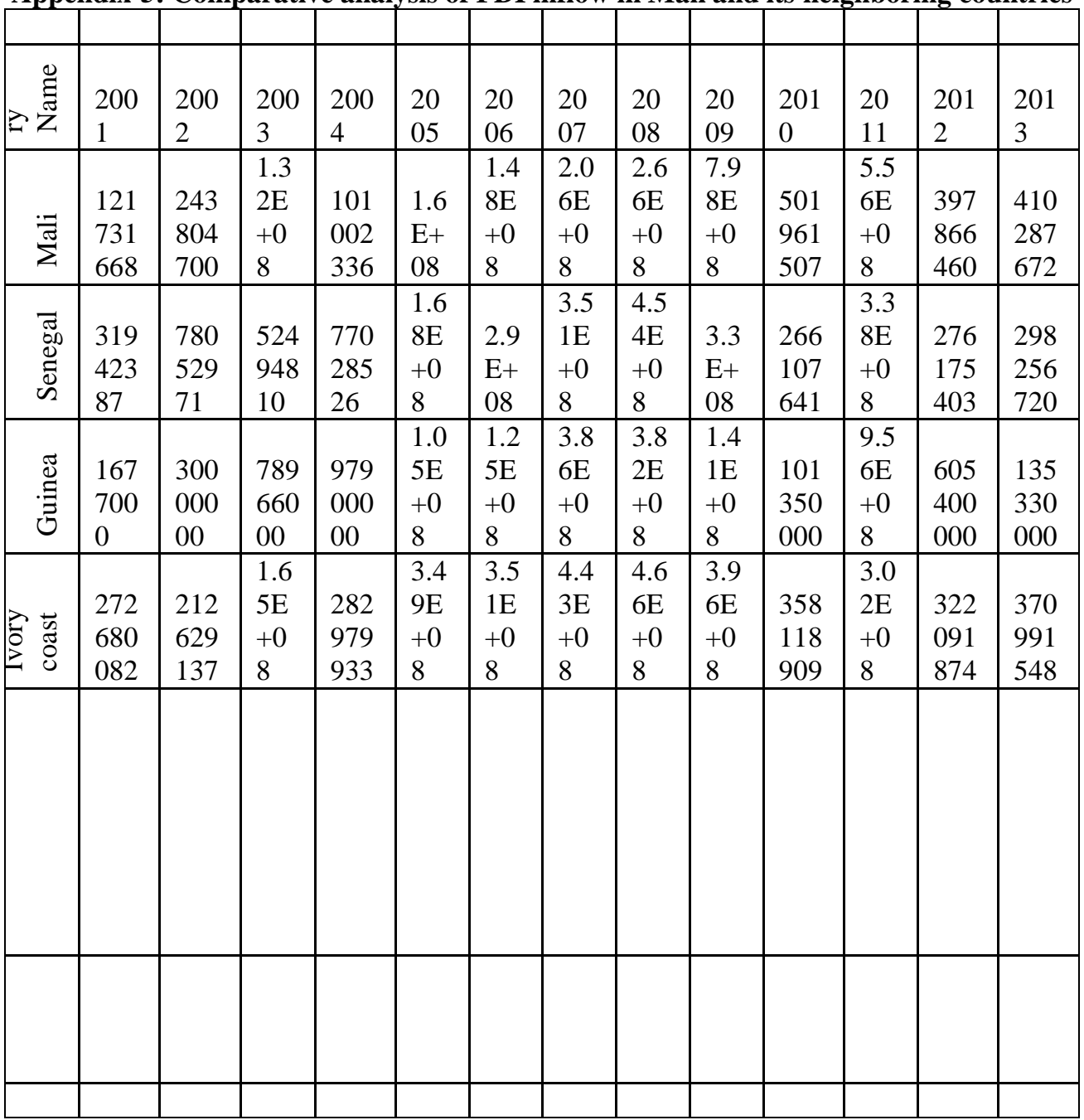

Appendix-6: Comparative analysis of GDP growth in Mali and its neighboring countries

\begin{tabular}{|l|l|l|l|l|l|l|l|l|l|l|l|l|l|}
\hline Cou & & & & & & & & & & & & & \\
ntry & & & & & & & & & & & & & \\
Nam & 200 & 20 & 20 & 20 & 20 & 20 & 20 & 20 & 20 & 20 & 20 & 201 & 20 \\
e & 1 & 02 & 03 & 04 & 05 & 06 & 07 & 08 & 09 & 10 & 11 & 2 & 13 \\
\hline & 12. & & & & & & & & & & & - & \\
Mali & 1 & 4.2 & 7.4 & 2.2 & 6.1 & 8.6 & 4.3 & 5.0 & 4.5 & 5.8 & 2.7 & 0.4 & 2.1 \\
\hline & 4.5 & 0.6 & 6.6 & 5.8 & 5.6 & 2.4 & 4.9 & 3.6 & 2.4 & 4.2 & 2.0 & 3.4 & 2.8 \\
& 809 & 54 & 83 & 70 & 22 & 61 & 38 & 82 & 23 & 66 & 66 & 529 & 03 \\
Sene & 164 & 80 & 22 & 77 & 60 & 57 & 48 & 52 & 17 & 24 & 64 & 025 & 80 \\
gal & 2 & 37 & 81 & 22 & 69 & 03 & 51 & 44 & 59 & 76 & 53 & 8 & 72 \\
\hline & & & & & & & & & - & & & & \\
& 3.6 & 5.1 & 1.2 & 2.3 & 2.9 & 2.4 & 1.7 & 4.9 & 0.2 & 1.9 & 3.9 & 3.9 & 2.2 \\
& 583 & 64 & 48 & 40 & 97 & 96 & 57 & 36 & 80 & 36 & 08 & 441 & 99 \\
Gui & 464 & 60 & 60 & 11 & 27 & 72 & 68 & 93 & 19 & 21 & 76 & 119 & 99 \\
nea & 7 & 95 & 13 & 73 & 26 & 86 & 24 & 27 & 2 & 74 & 14 & 9 & 92 \\
\hline & & - & - & & & & & & & & & & \\
Ivor & - & 1.4 & 1.5 & 1.7 & 1.2 & 1.5 & 1.7 & 2.5 & 3.2 & 2.0 & - & 10. & 8.7 \\
y & 0.0 & 30 & 55 & 93 & 55 & 15 & 65 & 42 & 51 & 17 & 4.3 & 674 & 00 \\
Coa & 212 & 80 & 36 & 85 & 96 & 84 & 03 & 84 & 45 & 63 & 87 & 085 & 77 \\
st & 305 & 8 & 5 & 52 & 8 & 24 & 68 & 15 & 37 & 86 & 26 & 4 & 74 \\
\hline
\end{tabular}

